Energy Materials and Solar Cells

Elsevier Editorial System(tm) for Solar

Manuscript Draft

Manuscript Number: SOLMAT-D-17-00752R1

Title: Development of low-cost inorganic salt hydrate as a thermochemical energy storage material

Article Type: Full Length Article

Keywords: thermochemical storage material; bischofite; isothermal

kinetics; dehydration reaction; salt hydrate

Corresponding Author: Dr. Svetlana Ushak, Doctor in Chemistry

Corresponding Author's Institution: University of Antofagasta

First Author: Veronica Mamani

Order of Authors: Veronica Mamani; Andrea Gutierrez; Svetlana Ushak, Doctor in Chemistry

Abstract: Thermochemical storage is based on a reversible chemical reaction; energy can be stored when an endothermic chemical reaction occurs and then, energy is released when it is reversed in an exothermic reaction. According to literature and based on the energy storage density (esd), MgCl2.6H2O is a promising candidate material for thermochemical energy storage. Bischofite is an inorganic salt obtained as a by-product material from extraction processes of non-metallic minerals, from salar de Atacama in Chile, containing approximately 95\% of MgCl2.6H2O. Thus, the purpose of this study was to characterize the dehydration reaction of bischofite ore, studied as a low-cost thermochemical storage material. Thermogravimetric data for bischofite were obtained using a TGA instrument coupled to a DSC, at four different isotherms $70{ }^{\circ} \mathrm{C}, 80^{\circ} \mathrm{C}, 90$ ${ }^{\circ} \mathrm{C}$ and $100{ }^{\circ} \mathrm{C}$. The results of conversion reaction $(\alpha-t)$ from the thermal dehydration experiments, demonstrated the first phase of dehydration with the loss of two water molecules. The study showed a typical sigmoid curve with a significant acceleration in the conversion at the beginning of the reaction until it reaches a maximum rate, where the curve keeps constant. The same behavior was observed for all the temperatures used. The kinetics of bischofite dehydration model was determined using the isothermal kinetics method. For this, the thermogravimetric data were fitted to the most used kinetic models (D, F, R, A) and then their respective correlation coefficients $\mathrm{R}$ were evaluated. The results indicated that the dehydration reaction of bischofite was described by the kinetics of chemical reaction of cylindrical particles $\mathrm{R} 2$. The rate of dehydration reaction and esd of bischofite are lower as compared to synthetic $\mathrm{MgCl} 2 \cdot 6 \mathrm{H} 20$, at temperatures higher than $80{ }^{\circ} \mathrm{C}$. However, the cost of materials to store $1 \mathrm{MJ}$ of energy is three times lower for bischofite, which is an evident advantage to promote the reuse of this material left as waste by the non-metallic industry. 
Bischofite main component is $\mathrm{MgCl}_{2} \cdot 6 \mathrm{H}_{2} \mathrm{O}$, a typical TCS material for seasonal storage

Bischofite dehydration and kinetic study are presented in this work

The rate of dehydration reaction of bischofite is lower compared with synthetic $\mathrm{MgCl}_{2} \cdot 6 \mathrm{H}_{2} \mathrm{O}$

The $e s d$ for bischofite are lower compared with synthetic $\mathrm{MgCl}_{2} \cdot 6 \mathrm{H}_{2} \mathrm{O}$

The cost to store $1 \mathrm{MJ}$ of energy is three times lower for bischofite 
1

\title{
Development of low-cost inorganic salt hydrate as a thermochemical energy storage material
}

\author{
V. Mamani ${ }^{l}$, A. Gutiérrez ${ }^{2}$, S. Ushak ${ }^{l^{*}}$ \\ ${ }^{I}$ Department of Chemical Engineering and Mineral Processing and Center for Advanced Study of Lithium \\ and Industrial Minerals (CELiMIN). Universidad de Antofagasta, Campus Coloso, Av. Universidad de \\ Antofagasta 02800, Antofagasta (Chile) \\ ${ }^{2}$ German Aerospace Center-DLR e. V., Institute of Technical Thermodynamics, Pfaffenwaldring 38, 70569 \\ Stuttgart, Germany \\ Corresponding author: svetlana.ushak@uantof.cl
}

\begin{abstract}
Thermochemical storage is based on a reversible chemical reaction; energy can be stored when an endothermic chemical reaction occurs and then, energy is released when it is reversed in an exothermic reaction. According to literature and based on the energy storage density (esd), $\mathrm{MgCl}_{2} \cdot 6 \mathrm{H}_{2} \mathrm{O}$ is a promising candidate material for thermochemical energy storage. Bischofite is an inorganic salt obtained as a by-product material from extraction processes of non-metallic minerals, from Salar de Atacama in Chile, containing approximately $95 \%$ of $\mathrm{MgCl}_{2} \cdot 6 \mathrm{H}_{2} \mathrm{O}$. Thus, the purpose of this study was to characterize the dehydration reaction of bischofite ore, studied as a low-cost thermochemical storage material. Thermogravimetric data for bischofite were obtained using a TGA instrument coupled to a DSC, at four different isotherms $70{ }^{\circ} \mathrm{C}, 80^{\circ} \mathrm{C}, 90^{\circ} \mathrm{C}$ and $100{ }^{\circ} \mathrm{C}$. The results of conversion reaction $(\alpha-t)$ from the thermal dehydration experiments, demonstrated the first phase of dehydration with the loss of two water molecules. The study showed a typical sigmoid curve with a significant acceleration in the conversion at the beginning of the reaction until it reaches a maximum rate, where the curve keeps constant. The same behavior was observed for all the temperatures used. The kinetics of bischofite dehydration model was determined using the isothermal kinetics method. For this, the thermogravimetric data were fitted to the most used kinetic models (D, F, R, A) and then their respective correlation coefficients $\mathrm{R}$ were evaluated. The results indicated that the dehydration reaction of bischofite was described by the kinetics of chemical reaction of cylindrical particles $\mathrm{R}_{2}$. The rate of dehydration reaction and esd of bischofite are lower as compared to synthetic $\mathrm{MgCl}_{2} \cdot 6 \mathrm{H}_{2} \mathrm{O}$, at temperatures higher than $80{ }^{\circ} \mathrm{C}$. However, the cost of materials to store $1 \mathrm{MJ}$ of energy is three times lower for bischofite, which is an evident advantage to promote the reuse of this material left as waste by the non-metallic industry.
\end{abstract}

Keywords: thermochemical storage material, bischofite, isothermal kinetics, dehydration reaction, salt hydrate. 
$\mathrm{J} / \mathrm{cm}^{3}$

$\mathrm{kg} / \mathrm{m}^{3}$

$\rho \quad$ Density

TES Thermal Energy Storage

a Fraction Reacted

THS Thermochemical Heat Storage

LHS Latent Heat Storage

SHS Sensible Heat Storage

PCM Phase Change Material

TCM Thermochemical Material

CHP Chemical heat pump

DTA Differential Thermal Analysis

DTG Derivative Thermogravimetric

IR Infrared Spectroscopy

SEM Scanning Electron Microscope

STA Simultaneous Thermal Analysis

EDX Energy dispersive X-ray

TG Thermogravimetry

MS Mass Spectrometer

DSC Differential Scanning Calorimetry

LM Mean Size

$\mu \mathrm{m}$

LD Mode Size

XRD X-Ray Diffraction

$\mathrm{t} / \mathrm{t}_{0.5} \quad$ Time/time $\alpha=0.5$

$\mathrm{E}_{\mathrm{a}} \quad$ Energy activation

A Frequency factor

$R \quad$ Correlation coefficient

$\mathrm{T} \quad$ Temperature

Slope

Intercept

$\Delta \mathrm{H}_{\mathrm{D}} \quad$ Dehydration enthalpy

$k \quad$ Rate constant

$\%$ wt Percentage of weight loss
${ }^{\circ} \mathrm{C}$

$\min$

$\mathrm{kJ} / \mathrm{kg}$

$\mu \mathrm{m}$

-

$\mathrm{J} / \mathrm{mol}$

$\mathrm{s}^{-1}$

$-$

-

$\%$ 


\section{Introduction}

Thermal energy storage (TES) is an available technology, where energy in the form of heat or cold is stored in materials (charging process) for a specific time, to be released in the form of heat (discharge process), which can be transformed into other forms of energy or simply used as heat, depending on energy demand. The incorporation of TES systems increases efficiency in solar energy use throughout 24 hours of the day, reduces loss of useful thermal energy and consequently favors the reduction of greenhouse gas emissions considerably [1].

The amount of thermal energy that can be stored and discharged depends on the characteristics of the storage material and the associated temperature effects between the storage medium and the energy source. Thermal energy can be stored by virtue of the internal energy change of a material caused by sensible heat, latent heat, and chemical reactions [1]. Sensible heat TES systems store energy through temperature change in the storage materials, where thermal energy is stored by raising the temperature of a material [2]. Latent heat is heat absorbed or released by a material, while changing its phase at constant temperature [3]. Latent heat is released when the phase change material (PCM) is cooled again and solidifies. However, the main disadvantages of these two, sensible and latent, heat storage forms are low energy density and considerable heat loss during storage. These disadvantages are overcome by the heat storage type occurring by means of a chemical reaction, also called thermochemical storage, since it keeps high energy density, which becomes 5 and 10 times greater, compared to latent heat and sensible heat storage systems, respectively. This thermochemical storage type is mainly based on obtaining heat by means of a reversible chemical reaction (See Figure 1 [4]). In this reaction, a thermochemical energy storage material (C) absorbs external heat (e.g. solar energy) through an endothermic reaction, decomposing into A and B. Products (A and B) are separated by physical means and stored in separate containers. When materials $\mathrm{A}$ and $\mathrm{B}$ are combined again, exothermic reverse reaction, generation of $\mathrm{C}$ and release of stored thermal energy occur [5].

Storage and transport times are theoretically unlimited because there is no heat loss during storage of materials A, B and C; thus, products can be stored at room temperature. Therefore, these are promising systems for long-term heat storage (as seasonal storage) [6,7]. Recent studies also show advances in applications of thermochemical storage systems at high temperature in CSP plants [8]. However, there is still little experience in the development of materials and systems for thermochemical storage. [9]. 
Figure 1: Thermochemical storage process cycle: charge, storage and discharge [4].

Reversible chemical reactions occurring between reactive components or pairs of reagents are largely responsible for thermal energy charge and discharge. The different reactions that have been studied for thermochemical storage are classified in the systems illustrated in Figure 2. Of these, salt hydrate pairs are potential candidates for thermal energy storage as, during the energy storage phase, when heated, they are converted into partially or completely anhydrous salts, through water release. These hydrophilic anhydrous salts can readily react with water to release stored heat during the discharge step. On the other hand, it is feasible to achieve long-term thermal energy storage by separating the anhydrous salt and water at room temperature (eq.1).

$$
\text { salt }+x \mathrm{H}_{2} \mathrm{O} \leftrightarrow \text { salt } \cdot x \mathrm{H}_{2} \mathrm{O}+\mathrm{Heat}
$$




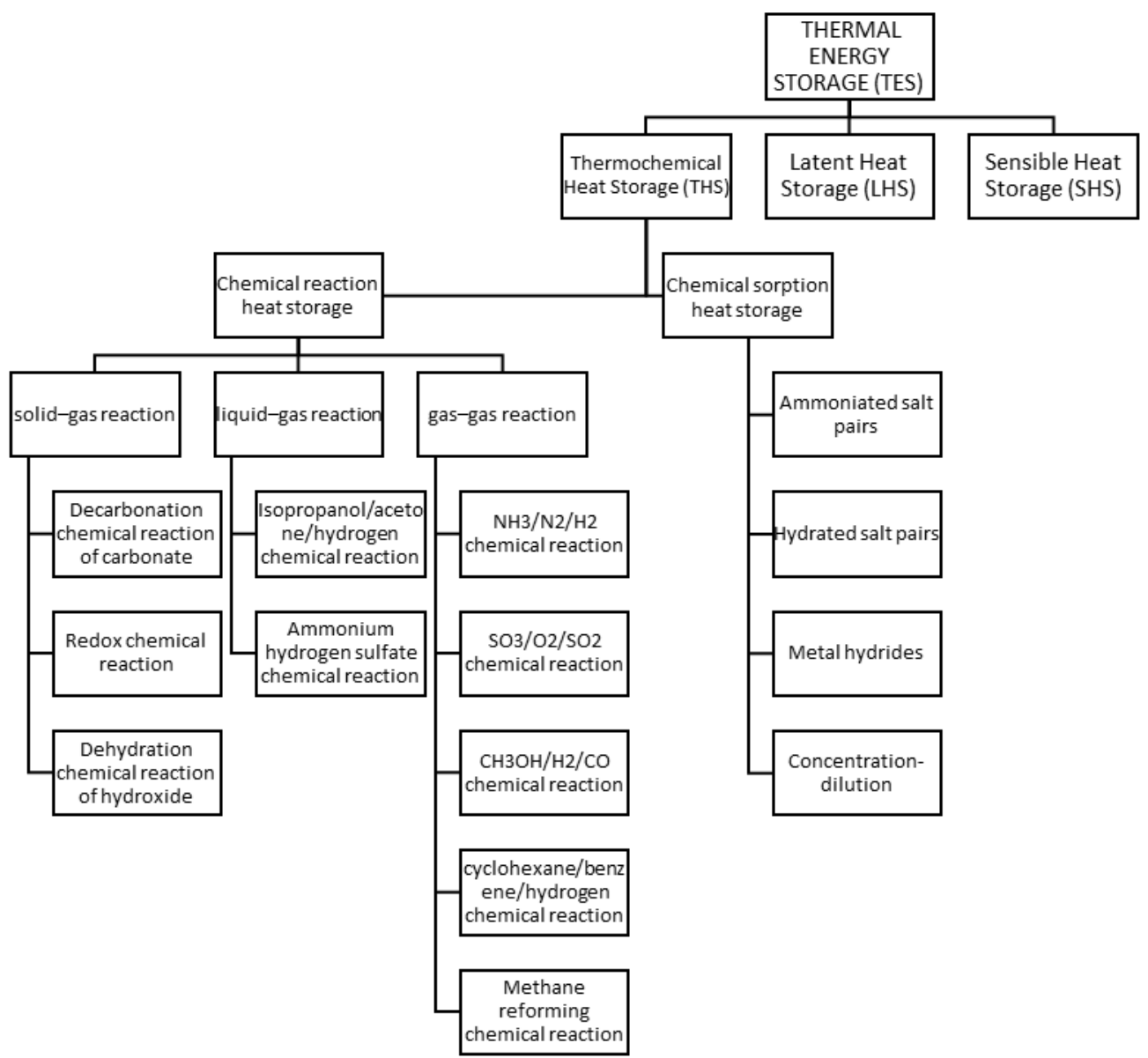

Figure 2: Materials and systems for thermochemical storage (based on [5, 9-11).

The Chilean Salar de Atacama brines, which are in a territory with very high solar radiation, are rich in salt hydrates. Due to their high availability and low cost, these salts can be studied and used to store thermal energy. In fact, since they are obtained as waste or by-products during brine concentration or during chemical conversion for production of lithium carbonate, among other compounds [12], it proves attractive to carry out studies for reusing these large quantities of salts as TES materials. One of the natural minerals precipitating at the evaporation ponds, during the brine concentration process at Salar de Atacama, is bischofite, composed mainly of $\mathrm{MgCl}_{2} \cdot 6 \mathrm{H}_{2} \mathrm{O}(>95$ wt.\%) with some impurities, such as $\mathrm{KCl}, \mathrm{NaCl}, \mathrm{Li}_{2} \mathrm{SO}_{4} \cdot \mathrm{H}_{2} \mathrm{O}$ and others [13].

Previous studies [14-21] of synthetic $\mathrm{MgCl}_{2} \cdot 6 \mathrm{H}_{2} \mathrm{O}$ salt indicate that it has a hydration/dehydration reaction suitable for thermochemical energy storage. In researches [15-21], the decomposition of pure magnesium chloride hexahydrate has been extensively studied. The studies determined four stages of $\mathrm{MgCl}_{2} \cdot 6 \mathrm{H}_{2} \mathrm{O}$ dehydration (eq. 2-5) under different dehydration conditions (Table 1). Equation 5 shows that a hydrolysis reaction occurs at the same time as the dehydration reaction of equation 4. 


$$
\begin{aligned}
& \mathrm{MgCl}_{2} \cdot 6 \mathrm{H}_{2} \mathrm{O}(\mathrm{s}) \leftrightarrow \mathrm{MgCl}_{2} \cdot 4 \mathrm{H}_{2} \mathrm{O}(\mathrm{s})+2 \mathrm{H}_{2} \mathrm{O}(\mathrm{g}) \\
& \mathrm{MgCl}_{2} \cdot 4 \mathrm{H}_{2} \mathrm{O}(\mathrm{s}) \leftrightarrow \mathrm{MgCl}_{2} \cdot 2 \mathrm{H}_{2} \mathrm{O}(\mathrm{s})+2 \mathrm{H}_{2} \mathrm{O}(\mathrm{g}) \\
& \mathrm{MgCl}_{2} \cdot 2 \mathrm{H}_{2} \mathrm{O}(\mathrm{s}) \leftrightarrow \mathrm{MgCl}_{2} \cdot \mathrm{H}_{2} \mathrm{O}(\mathrm{s})+\mathrm{H}_{2} \mathrm{O}(\mathrm{g}) \\
& \mathrm{MgCl}_{2} \cdot 2 \mathrm{H}_{2} \mathrm{O}(\mathrm{s}) \leftrightarrow \mathrm{MgOHCl}(\mathrm{s})+\mathrm{H}_{2} \mathrm{O}(\mathrm{g})+\mathrm{HCl}(\mathrm{g})
\end{aligned}
$$

\begin{tabular}{|c|c|c|c|}
\hline Dehydration reactions & $\mathbf{T}\left({ }^{\circ} \mathbf{C}\right)$ & $\begin{array}{c}\text { Heating rate } \\
(\mathrm{K} / \mathrm{min})\end{array}$ & Ref \\
\hline \multirow{7}{*}{$\mathrm{MgCl}_{2} \cdot 6 \mathrm{H}_{2} \mathrm{O} \rightarrow \mathrm{MgCl}_{2} \cdot 4 \mathrm{H}_{2} \mathrm{O}+2 \mathrm{H}_{2} \mathrm{O}$} & 27- 108 & 2 & {$[15]$} \\
\hline & 69- 106 & 5 & {$[16]$} \\
\hline & 116.7 & n.a. & [17] \\
\hline & 96 & 5 & {$[18]$} \\
\hline & $118-150$ & 10 & [19] \\
\hline & $50-90$ & 1 & {$[20]$} \\
\hline & 82 & 1 & {$[21]$} \\
\hline \multirow{7}{*}{$\mathrm{MgCl}_{2} \cdot 4 \mathrm{H}_{2} \mathrm{O} \rightarrow \mathrm{MgCl}_{2} \cdot 2 \mathrm{H}_{2} \mathrm{O}+2 \mathrm{H}_{2} \mathrm{O}$} & $108-144$ & 2 & {$[15]$} \\
\hline & $129-150$ & 5 & {$[16]$} \\
\hline & 182.5 & n.a. & [17] \\
\hline & 107 & 5 & {$[18]$} \\
\hline & $150-176$ & n.a. & [19] \\
\hline & $90-120$ & 1 & {$[20]$} \\
\hline & 116 & 1 & {$[21]$} \\
\hline \multicolumn{4}{|l|}{ Dehydration Thermal hydrolysis } \\
\hline $\mathrm{MgCl}_{2} \cdot 2 \mathrm{H}_{2} \mathrm{O} \rightarrow a \mathrm{MgCl}_{2} \cdot n \mathrm{H}_{2} \mathrm{O}+b \mathrm{MgOHCl}+b \mathbf{H C l}+(2-n a-b)$ & $144-178$ & 2 & {$[15]$} \\
\hline $\mathrm{H}_{2} \mathrm{O}$ & $167-181$ & 5 & {$[16]$} \\
\hline \multirow[t]{4}{*}{$(1 \leq n \leq 2, a+b=1)$} & 240 & n.a. & {$[17]$} \\
\hline & 193 & 5 & {$[18]$} \\
\hline & $185-234$ & 10 & [19] \\
\hline & $120-210$ & 1 & {$[20]$} \\
\hline $\mathrm{MgCl}_{2} \cdot \mathrm{H}_{2} \mathrm{O}(\mathrm{s}) \rightarrow \mathrm{MgOHCl} \cdot \mathrm{H}_{2} \mathrm{O}(\mathrm{s})+\mathbf{H C l}(\mathrm{g})$ & $150-210$ & 1 & {$[20]$} \\
\hline $\mathrm{MgCl}_{2} \cdot 2 \mathrm{H}_{2} \mathrm{O}(\mathrm{s}) \rightarrow \mathrm{MgOHCl} \cdot \mathrm{H}_{2} \mathrm{O}(\mathrm{s})+\mathbf{H C l}(\mathrm{g})$ & 145 & 1 & {$[21]$} \\
\hline
\end{tabular}

Table 1: Previously studied $\mathrm{MgCl}_{2} \cdot 6 \mathrm{H}_{2} \mathrm{O}$ dehydration conditions.

More recent studies propose the application of synthetic $\mathrm{MgCl}_{2} \cdot 6 \mathrm{H}_{2} \mathrm{O}$ salt as phase change material (PCM) for latent heat storage. Thus, several works focused on properties characterization, such as heat capacity and melting temperature [22-29], obtaining promising results to utilize this material for latent heat storage. On these grounds, studies by Ushak et al. [13] have been conducted with bischofite, natural mineral from Salar de Atacama, which characterized the physical and thermal 
properties of this material for use as PCM. Results indicated that bischofite exhibits thermal properties similar to synthetic salt hydrate.

Recent studies have focused on the use of synthetic $\mathrm{MgCl}_{2} \cdot 6 \mathrm{H}_{2} \mathrm{O}$ as a thermochemical material (TCM) because the thermal decomposition of this salt occurs by means of a chemical dehydration reaction and stores a high energy density. $\mathrm{MgCl}_{2} \cdot 6 \mathrm{H}_{2} \mathrm{O}$ dehydration/hydration reactions were described by some authors [14, 21, 30-32], and it was possible to determine the different charging and discharging operating temperatures of the material and the energy storage density eds (see Table 2).

Table 2: Charging and discharging operating for $\mathrm{MgCl}_{2} \cdot 6 \mathrm{H}_{2} \mathrm{O}$ hydration and dehydration.

\begin{tabular}{|c|c|c|c|c|c|c|}
\hline Reaction & $\begin{array}{c}\text { Charging } \\
\text { temperature }\left({ }^{\circ} \mathbf{C}\right)\end{array}$ & $\begin{array}{c}\text { Discharging } \\
\text { temperature }\left({ }^{\circ} \mathbf{C}\right)\end{array}$ & $\begin{array}{c}\Delta \mathrm{rH} \\
(\mathrm{kJ} / \mathbf{m o l})\end{array}$ & $\begin{array}{c}E d s \\
\left(\mathbf{J} / \mathrm{cm}^{3}\right)\end{array}$ & $\begin{array}{l}\text { Pressure } \\
\text { (kPa) }\end{array}$ & Reference \\
\hline $\mathrm{MgCl}_{2} \cdot 6 \mathrm{H}_{2} \mathrm{O} \rightarrow \mathrm{MgCl}_{2} \cdot 2 \mathrm{H}_{2} \mathrm{O}+4 \mathrm{H}_{2} \mathrm{O}$ & 150 & $25-50$ & $\ldots$ & - & 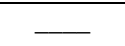 & [14] \\
\hline $\mathrm{MgCl}_{2} \cdot 2 \mathrm{H}_{2} \mathrm{O}+4 \mathrm{H}_{2} \mathrm{O} \rightarrow \mathrm{MgCl}_{2} \cdot 6 \mathrm{H}_{2} \mathrm{O}$ & $115-130$ & 35 & & 5 & 2.0 & [31] \\
\hline $\mathrm{MgCl}_{2} \cdot 6 \mathrm{H}_{2} \mathrm{O} \rightarrow \mathrm{MgCl}_{2} \cdot 2 \mathrm{H}_{2} \mathrm{O}+4 \mathrm{H}_{2} \mathrm{O}$ & 118 & $30-50$ & 220 & 1890 & 1.3 & [30] \\
\hline $\mathrm{MgCl}_{2} \cdot 6 \mathrm{H}_{2} \mathrm{O} \rightarrow \mathrm{MgCl}_{2} \cdot 2 \mathrm{H}_{2} \mathrm{O}+4 \mathrm{H}_{2} \mathrm{O}$ & 116 & 30 & 273 & 2110 & --- & [21] \\
\hline $\mathrm{MgCl}_{2} \cdot 2 \mathrm{H}_{2} \mathrm{O}+4 \mathrm{H}_{2} \mathrm{O} \rightarrow \mathrm{MgCl}_{2} \cdot 6 \mathrm{H}_{2} \mathrm{O}$ & 116 & 30 & 315 & 2435 & 1.9 & [21] \\
\hline $\mathrm{MgCl}_{2} \cdot 4.7 \mathrm{H}_{2} \mathrm{O}+1.3 \mathrm{H}_{2} \mathrm{O} \rightarrow \mathrm{MgCl}_{2} \cdot 6 \mathrm{H}_{2} \mathrm{O}$ & 105 & 25 & 72 & 551 & $2.0-2.1$ & [32] \\
\hline
\end{tabular}

From table 2, Essen et al. [14] characterized $\mathrm{MgCl}_{2} \cdot 6 \mathrm{H}_{2} \mathrm{O}$ salt hydrate dehydration for seasonal thermochemical storage applications under practical conditions, using TG-DSC equipment and a fixed bed reactor. Another experimental study was carried out by Zondag et al. [20,30], who performed TG tests by measuring $\mathrm{MgCl}_{2} \cdot 6 \mathrm{H}_{2} \mathrm{O}$ mass as a function of temperature increase, in which researchers obtained a dehydration start at $50{ }^{\circ} \mathrm{C}$ and the formation of $\mathrm{MgCl}_{2} \cdot \mathrm{H}_{2} \mathrm{O}$ at around $120^{\circ} \mathrm{C}$.

Kokouvi et al. [32] studied $\mathrm{MgCl}_{2} \cdot 6 \mathrm{H}_{2} \mathrm{O}$, intended for thermochemical energy storage applications at temperatures below $105{ }^{\circ} \mathrm{C}$ in a micro-CHP (chemical heat pump), due to the low melting point of the material, obtaining a low hydration reaction temperature of $35^{\circ} \mathrm{C}$, applicable only for heating supply for living spaces.

Further experimental studies on kinetics were carried out by Rammelberg et al. [21], using the simultaneous thermal analysis (STA) method, where dehydration reaction $\left(\mathrm{MgCl}_{2} \cdot 6 \mathrm{H}_{2} \mathrm{O}\right.$ (s) to $\left.\mathrm{MgCl}_{2} \cdot 2 \mathrm{H}_{2} \mathrm{O}(\mathrm{s})\right)$, obtained a reaction enthalpy $(\Delta \mathrm{H})$ of $1344 \mathrm{~J} / \mathrm{g}$.

The more recent and advanced work has achieved the development of suitable technology to apply $\mathrm{MgCl}_{2} \cdot 6 \mathrm{H}_{2} \mathrm{O}$ as a thermochemical storage material. Zondag et al. [33], constructed a sorption heat storage system, a compact bed sorption system containing $17 \mathrm{dm}^{3}$, capable of generating $150 \mathrm{~W}$ of thermal power, from an airflow of 510 1/min with a vapor pressure of $12 \mathrm{mbar}$. The bed can produce 
heat over $40 \mathrm{~h}$, indicating an effective energy density of approximately $0.5 \mathrm{GJ} / \mathrm{m}^{3}$ under the present conditions. However, due to heat losses, this system is still to be improved.

The first studies on $\mathrm{MgCl}_{2} \cdot 6 \mathrm{H}_{2} \mathrm{O}$ thermal decomposition mechanisms were carried out by Kirsh et al [19], followed by Kashani-Nejad et al. [17, 34, 35], Kunihisa Sugimoto et al. [18] and Huang et al., [15], who, using DTA, TG, derivative thermogravimetry (DTG), infrared (IR) spectroscopy, Xray diffraction (XRD), (SEM) and chemical analysis of magnesium and chloride techniques, identified different intermediate phases of $\mathrm{Mg}(\mathrm{OH}) \mathrm{Cl} \cdot \mathrm{n}_{2} \mathrm{O}(0 \leq \mathrm{n} \leq 1)$ at high temperatures.

The kinetic study was performed by Kirsh et al. [19], and Huang et al. [15], using thermogravimetric techniques, under different working conditions. The authors determined salt dehydration in 3 steps and established the activation energy and frequency factor kinetic parameters.

One of the areas of greatest interest in research on thermochemical storage systems, is the development and characterization of materials and chemical reactions, since performance of each system depends to a large extent on the properties of materials and on reaction kinetics. In order to obtain a detailed and adequate characterization of reaction kinetics involving salt hydrates, it is necessary to consider changes in crystallographic structure, water stability within the crystalline structure, particle size and the presence of impurities, since kinetic measures may change depending on the characteristics of the solid material [36]. On the other side, for the successful implementation of thermochemical storage systems, the development of low cost materials is necessary. Consequently, many scientists carry out their investigation using recycled materials and revalorizing industrial waste and by-products [37-40].

Aligned with this statement, the aim of this work was studying bischofite, an inorganic mineral waste, precipitated in solar evaporation ponds during the concentrations lithium brines as candidate for using in thermochemical storage systems. The cost of this material is of about 40 US\$/ton [13] being almost four times less than the cost of synthetic magnesium chloride hydrate.

In addition, this research accomplishes a double objective: on one side, the implementation of an economically viable storage system based on new low-cost materials and on the other side, the revalorization of industrial waste material, which will contribute to economic, environmental and societal gains such as reducing landfill waste amounts, creation of value-added materials and others. Thus, the mechanism and kinetics of the dehydration reaction of bischofite were established, and its chemical, physical and thermal properties were characterized by its application as a THS material. The same characterization procedure was carried out for synthetic $\mathrm{MgCl}_{2} \cdot 6 \mathrm{H}_{2} \mathrm{O}$ and obtained results for both materials were compared as well as esd and the cost of TES systems. 


\section{MATERIALS AND METHODS}

\subsection{Materials}

Bischofite, provided by Salmag Company from Antofagasta Region, Chile, obtained from the brines concentration process, was used for research. The $10 \mathrm{~kg}$ bischofite sample was homogenized by manual mixing, subjected to a drying heat treatment at $40{ }^{\circ} \mathrm{C}$ for 12 hours to remove environmental humidity, and finally, divided into $1 \mathrm{~kg}$ samples and packed to be used in different characterization studies. Merck-branded synthetic $\mathrm{MgCl}_{2} \cdot 6 \mathrm{H}_{2} \mathrm{O}(>99 \%$ purity) was used as comparison material which, like bischofite, was dried for 12 hours at $40{ }^{\circ} \mathrm{C}$. Finally, samples were kept in a desiccator.

\subsection{Chemical characterization method}

For chemical analysis, a mass of approximately $100 \mathrm{~g}$ of bischofite was used. Methods used for elements determination were: Atomic absorption spectrophotometry with direct aspiration (Varian Spectraa 220fs atomic absorption spectrometer) for sodium, potassium, calcium, lithium and magnesium identification; volumetric titration with $\mathrm{AgNO}_{3}$ for chloride identification and volumetric titration with $\mathrm{BaCl}_{2}$ for sulfate identification.

\subsection{Particle size characterization}

Sample particle size was determined using different mesh size sieves (see Table 3) coupled to Rotap, Retsch AS 200.

Table 3: Retsch mesh sizes.

\begin{tabular}{ccc}
\hline Mesh No. & Mesh size $(\mathbf{m m})$ & Mesh size $(\boldsymbol{\mu m})$ \\
\hline $\mathbf{1 2}$ & 1.70 & 1700 \\
$\mathbf{1 4}$ & 1.40 & 1400 \\
$\mathbf{1 6}$ & 1.18 & 1180 \\
$\mathbf{1 8}$ & 1.00 & 1000 \\
$\mathbf{2 0}$ & 0.850 & 850 \\
$\mathbf{3 0}$ & 0.600 & 600 \\
$\mathbf{4 0}$ & 0.425 & 425 \\
$\mathbf{5 0}$ & 0.300 & 300 \\
Base & 0 & 0
\end{tabular}

For this measurement, sieves were cleaned and weighed. Then, bischofite and magnesium chloride hexahydrate (38 and 50 grams' mass, respectively) samples were added to the sieves and these were subjected to $1.20 \mathrm{~mm} / \mathrm{g}$ vibration for 10 minutes, for salt distribution between the different mesh 
sizes. Upon completion, each sieve was weighed and mass retained in each one was recorded. Tests, for both bischofite and $\mathrm{MgCl}_{2} \cdot 6 \mathrm{H}_{2} \mathrm{O}$, were performed in triplicate and the average result was reported in this work.

\subsection{Thermal stability}

Thermal stability was measured with a METTLER TOLEDO TGA-DSC STARe thermogravimetric analyzer (TGA), using a dynamic method from room temperature up to $900{ }^{\circ} \mathrm{C}$ at a heating rate of 1 $\mathrm{K} / \mathrm{min}$. Nitrogen flow rate was $25.0 \mathrm{~mL} / \mathrm{min}$. For this analysis, a sample amount of approximately $17 \mathrm{mg}$ and a $70 \mu \mathrm{L}$ platinum crucible with an unsealed lid were used.

\subsection{Study of the dehydration mechanism and kinetic parameters}

Kinetic data were determined with the isothermal method at $70{ }^{\circ} \mathrm{C}, 80^{\circ} \mathrm{C}, 90{ }^{\circ} \mathrm{C}$ and $100{ }^{\circ} \mathrm{C}$, using a heating rate of $20 \mathrm{~K} / \mathrm{min}$ from room temperature up to respective temperature. The duration of the isothermal kinetic study was four hours, the METTLER TOLEDO TGA-DSC STARe device with a nitrogen flow rate of $25.0 \mathrm{~mL} / \mathrm{min}$. 10 to $20 \mathrm{mg}$ samples in a $70 \mu \mathrm{L}$ platinum crucible with an unsealed lid were used for each isotherm. Finally, data obtained were fitted to isothermal kinetic models of solid-gaseous type reactions which are more widely used (see Table 4 [41]). Each kinetic model and the corresponding curves are shown in Figure 3 to facilitate compression of the reaction compartment as a function of time. The fitting method used was described by Sharp et al. [42], as well as the calculation of the correlation coefficient $\mathrm{R}$.

Table 4: Solid state reaction equation models, commonly used for kinetic study [41].

\begin{tabular}{lcl}
\hline Reaction Model & Code & Kinetic Equation $\boldsymbol{f ( \alpha )}$ \\
\hline Uni-dimensional diffusion & $D_{1}$ & $\alpha^{2}=k t$ \\
Bi-dimensional diffusion & $D_{2}$ & $(1-\alpha) \ln (1-\alpha)+\alpha=k t$ \\
Tri-dimensional diffusion & $D_{3}$ & {$\left[1-(1-\alpha)^{1 / 3}\right]^{2}=k t$} \\
Ginstling-Brounshtein & $D_{4}$ & $1-(2 / 3) \alpha-(1-\alpha)^{2 / 3}=k t$ \\
First order & $F_{1}$ & $-\ln (1-\alpha)=k t$ \\
Cylindrical contraction & $R_{2}$ & $1-(1-\alpha)^{1 / 2}=k t$ \\
Spherical contraction & $R_{3}$ & $1-(1-\alpha)^{1 / 3}=k t$ \\
Zero Order & $O$ & $\alpha=k t$ \\
Avrami-Erofeyev & $A_{2}$ & {$[-\ln (1-\alpha)]^{1 / 2}=k t$} \\
Avrami-Erofeyev & $A_{3}$ & {$[-\ln (1-\alpha)]^{1 / 3}=k t$} \\
\hline
\end{tabular}




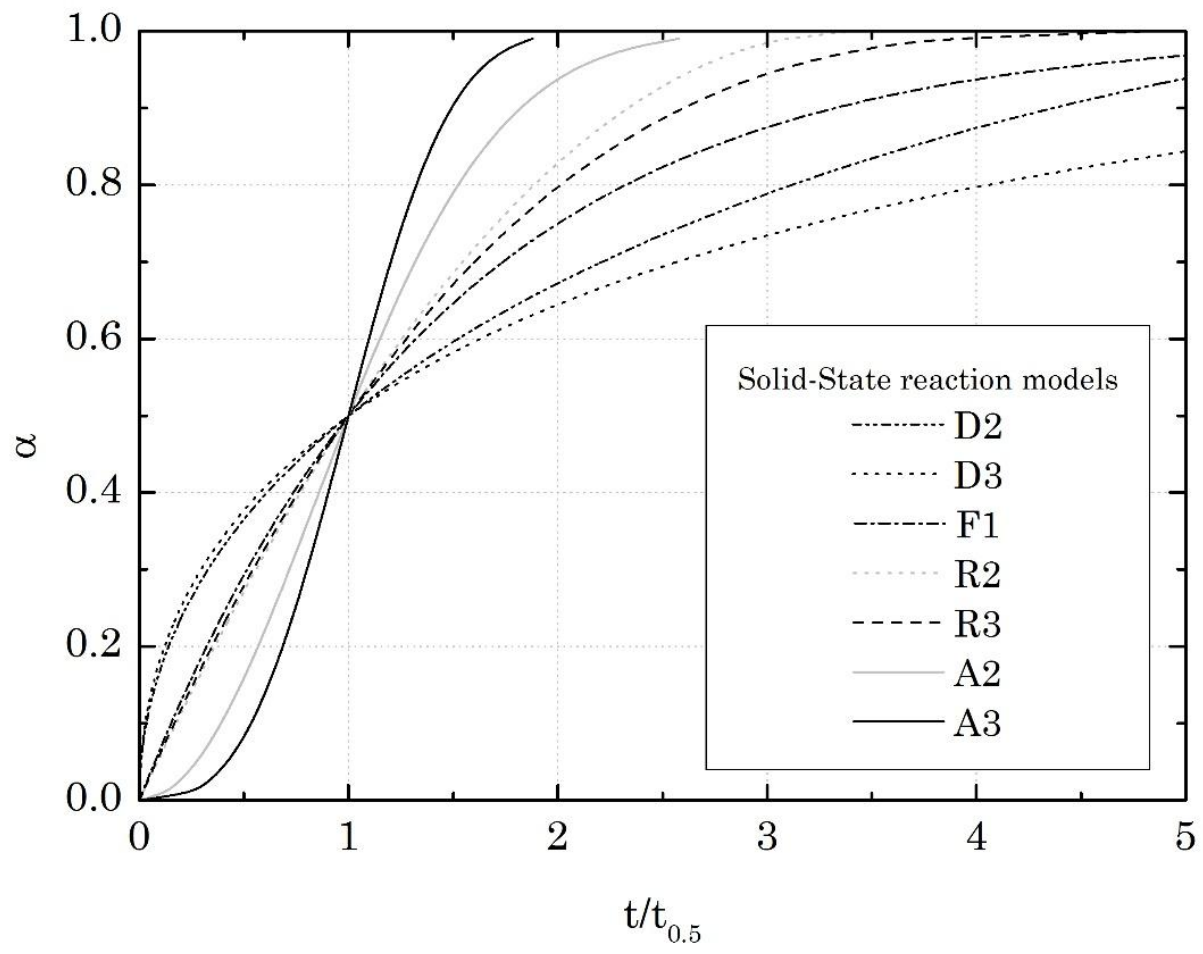

Figure 3: Values of $\alpha \mathrm{vs} t / \mathrm{t}_{0.5}$ for the solid-state reaction equations of Table 4.

Activation energy and frequency factor kinetic parameters were determined with the Arrhenius linearized equation (eq. 6), which was plotted according to the kinetic constants, obtained from the kinetic equation model best fitted to experimental data, with the inverse of time (1/T) in Kelvin.

$$
\ln k=\frac{-E a}{R} \cdot \frac{1}{T}+\ln A
$$

\subsection{Analysis of energy storage density (esd) and storage cost}

Reaction enthalpy $\left(\Delta \mathrm{H}_{\mathrm{D}}\right)$ was measured as the area under the curve DSC for the isothermal temperatures of $70^{\circ} \mathrm{C}, 80^{\circ} \mathrm{C}, 90^{\circ} \mathrm{C}$ and $100^{\circ} \mathrm{C}$, dates given by the METTLER TOLEDO TGA-DSC STARe device. The dehydration reaction lets an exothermic peak, therefore $\Delta H_{D}$ corresponds to the heat reaction.

Thermochemical esd in bischofite was calculated as the product of the reaction enthalpy and bischofite density and compared to the values obtained for pure $\mathrm{MgCl}_{2} \cdot 6 \mathrm{H}_{2} \mathrm{O}$ sample. 


\section{RESULTS AND DISCUSSION}

\subsection{Chemical characterization}

According to the chemical analysis of the bischofite sample, chemical elements found are listed in Table 5 with their respective concentrations.

Table 5: Bischofite chemical analysis.

\begin{tabular}{lc}
\hline \multicolumn{1}{c}{ Elements } & $\begin{array}{c}\text { Composition used in this study } \\
(\% \mathbf{w} / \mathbf{w} \mathbf{0 . 0 0 0 5})\end{array}$ \\
\hline Lithium, $\mathrm{Li}$ & 0.4227 \\
Sodium, $\mathrm{Na}$ & 0.2594 \\
Potassium, $\mathrm{K}$ & 0.2040 \\
Magnesium, $\mathrm{Mg}$ & 10.8092 \\
Calcium, $\mathrm{Ca}$ & 0.0139 \\
Chloride, $\mathrm{Cl}$ & 33.3595 \\
Sulfate, $\mathrm{SO}_{4}$ & 0.2260 \\
Moisture & 1.8521 \\
\hline
\end{tabular}

The results of the chemical analysis were used for the mineralization of the main phases present in the bischofite sample (see Figure 4). It is observed that $\mathrm{MgCl}_{2} \cdot 6 \mathrm{H}_{2} \mathrm{O}$ salt hydrate is present in $97.4 \%$, mixed with other salts in small quantities: carnallite $\mathrm{KCl} \cdot \mathrm{MgCl}_{2} \cdot 6 \mathrm{H}_{2} \mathrm{O}$ (1.6\%), sodium chloride $(0.7 \%)$, lithium sulfate monohydrate $\mathrm{Li}_{2} \mathrm{SO}_{4} \cdot \mathrm{H}_{2} \mathrm{O}(0.3 \%)$ and potassium chloride $\mathrm{KCl}$ $(0.03 \%)$.

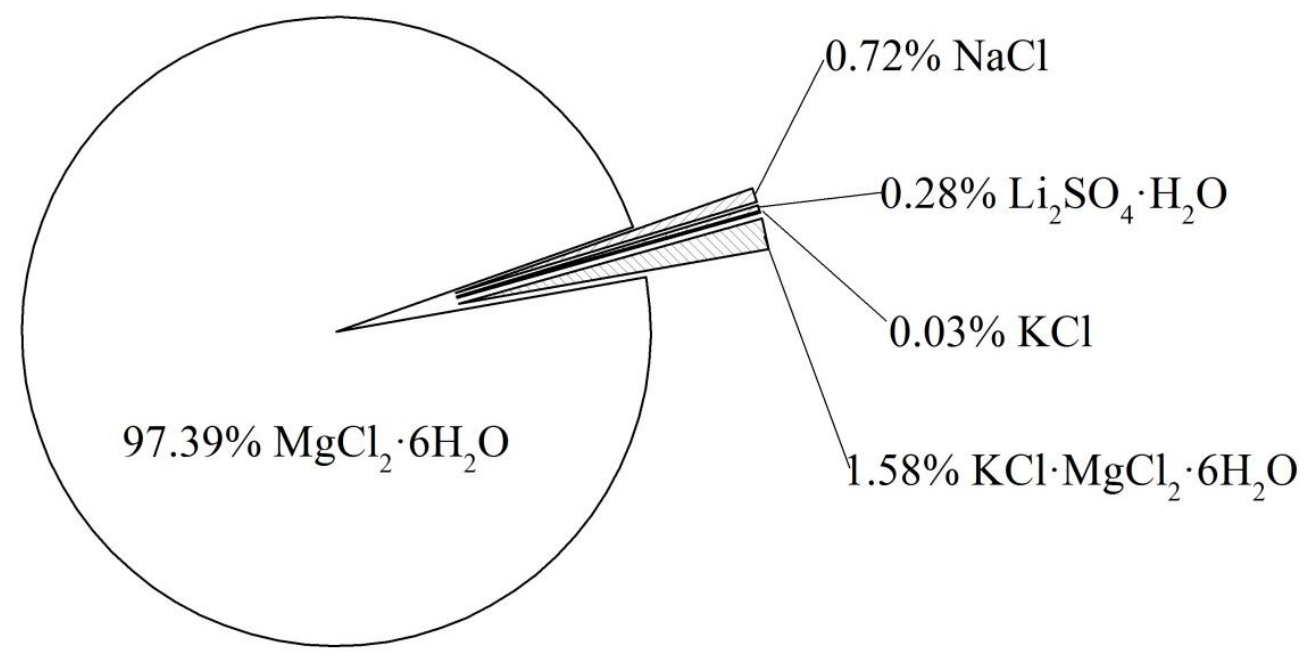

Figure 4: Bischofite mineralization

Mineralization of the bischofite sample is supported by XRD and SEM-EDX analysis previously published by Ushak et al. [13]. In that work, XRD analysis confirmed that the sample contained 
bischofite and SEM-EDX analysis confirmed the presence of a primary phase of bischofite, $\mathrm{MgCl}_{2} \cdot 6 \mathrm{H}_{2} \mathrm{O}$, and impurities, based on $\mathrm{K}-\mathrm{Cl}$, Na-Cl, S-O (attributed to $\mathrm{Li}_{2} \mathrm{SO}_{4} \cdot \mathrm{H}_{2} \mathrm{O}$ ) and $\mathrm{K}-\mathrm{Mg}-\mathrm{Cl}-$ $\mathrm{O}$ (attributed to $\mathrm{KCl} \cdot \mathrm{MgCl}_{2} \cdot 6 \mathrm{H}_{2} \mathrm{O}$ ). In addition, this analysis informed on the ill-defined cylindrical shape morphology observed in $\mathrm{MgCl}_{2} \cdot 6 \mathrm{H}_{2} \mathrm{O}$ crystals, due to the high hygroscopicity of the material. Sulfate and sodium chloride impurities morphologies were identified with rectangular and cubic crystal shapes, respectively.

\subsection{Particle size}

Particle size distributions in bischofite and $\mathrm{MgCl}_{2} \cdot 6 \mathrm{H}_{2} \mathrm{O}$ samples are shown in Tables 6 and 7 , respectively.

Table 6: Bischofite particle size distribution

\begin{tabular}{cccc}
\hline Average mesh size $(\mu \mathrm{m})$ & Retained mass $(\mathrm{g})$ & \% Retained mass & \% Cumulative mass \\
\hline 1700 & 0 & 0 & 100 \\
1550 & 20.68 & 53.82 & 100 \\
1290 & 10.63 & 27.68 & 46.178 \\
1090 & 5.59 & 14.55 & 18.503 \\
925 & 1.35 & 3.520 & 3.9553 \\
725 & 0.17 & 0.430 & 0.4305 \\
512.5 & 0 & 0 & 0 \\
362.5 & 0 & 0 & 0 \\
150 & 0 & 0 & 0 \\
\hline
\end{tabular}

Table 7: $\mathrm{MgCl}_{2} \cdot 6 \mathrm{H}_{2} \mathrm{O}$ particle size distribution

\begin{tabular}{cccc}
\hline Average mesh size $(\mu \mathrm{m})$ & Retained mass $(\mathrm{g})$ & \% Retained mass & \% Cumulative mass \\
\hline 1700 & 0.92 & 1.85 & 100 \\
1550 & 1.04 & 2.09 & 98.145 \\
1290 & 1.73 & 3.47 & 96.058 \\
1090 & 3.62 & 7.27 & 92.585 \\
925 & 6.23 & 12.52 & 85.316 \\
725 & 15.68 & 31.51 & 72.792 \\
512.5 & 11.14 & 22.38 & 41.285 \\
362.5 & 7.10 & 14.27 & 18.902 \\
150 & 2.31 & 4.64 & 4.6356 \\
\hline
\end{tabular}

Figures 5 and 6 present the quantification of the mean size (LM) and mode size (LD). 


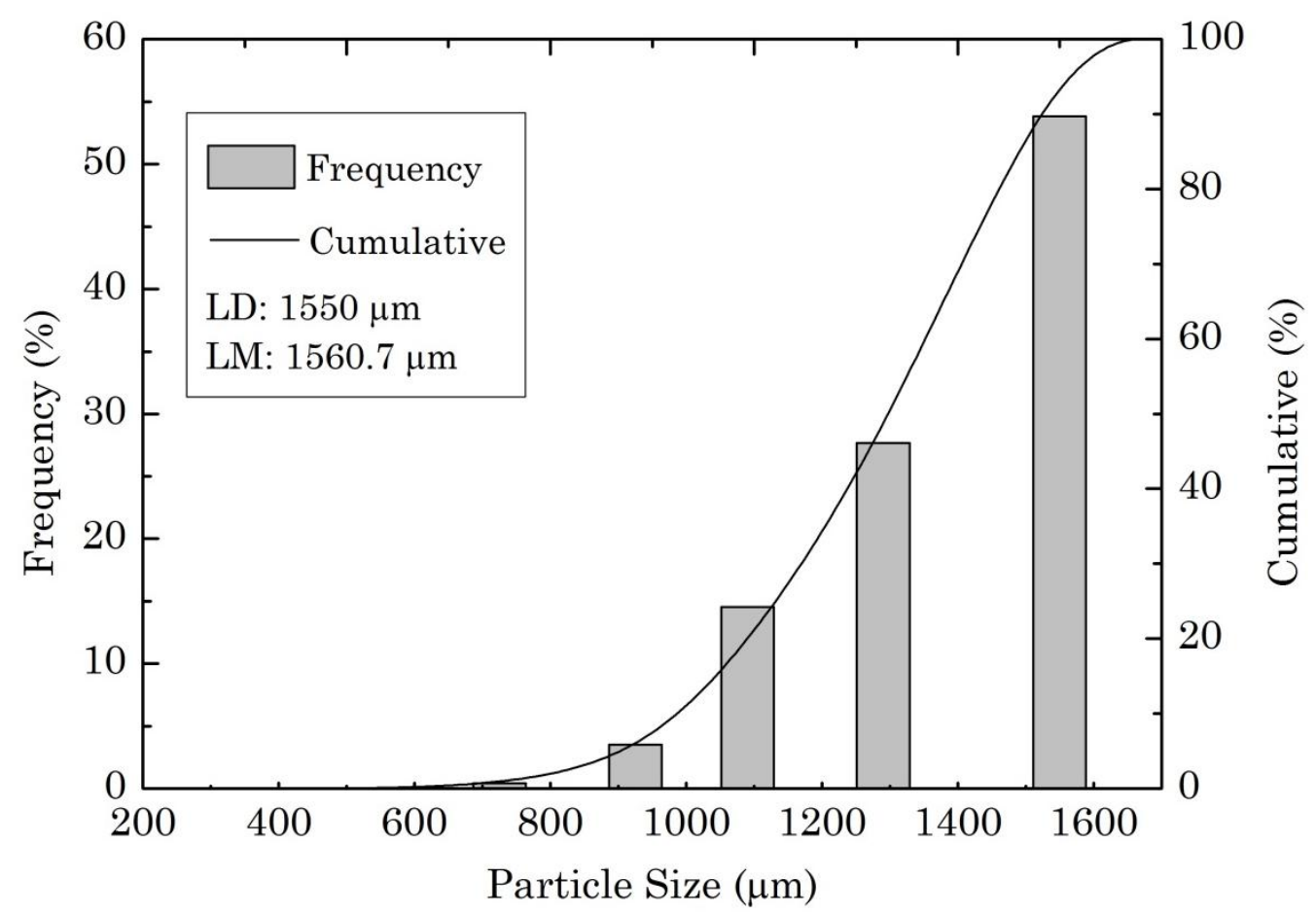

Figure 5: Bischofite size distribution. LD (mode size), LM (mean size).

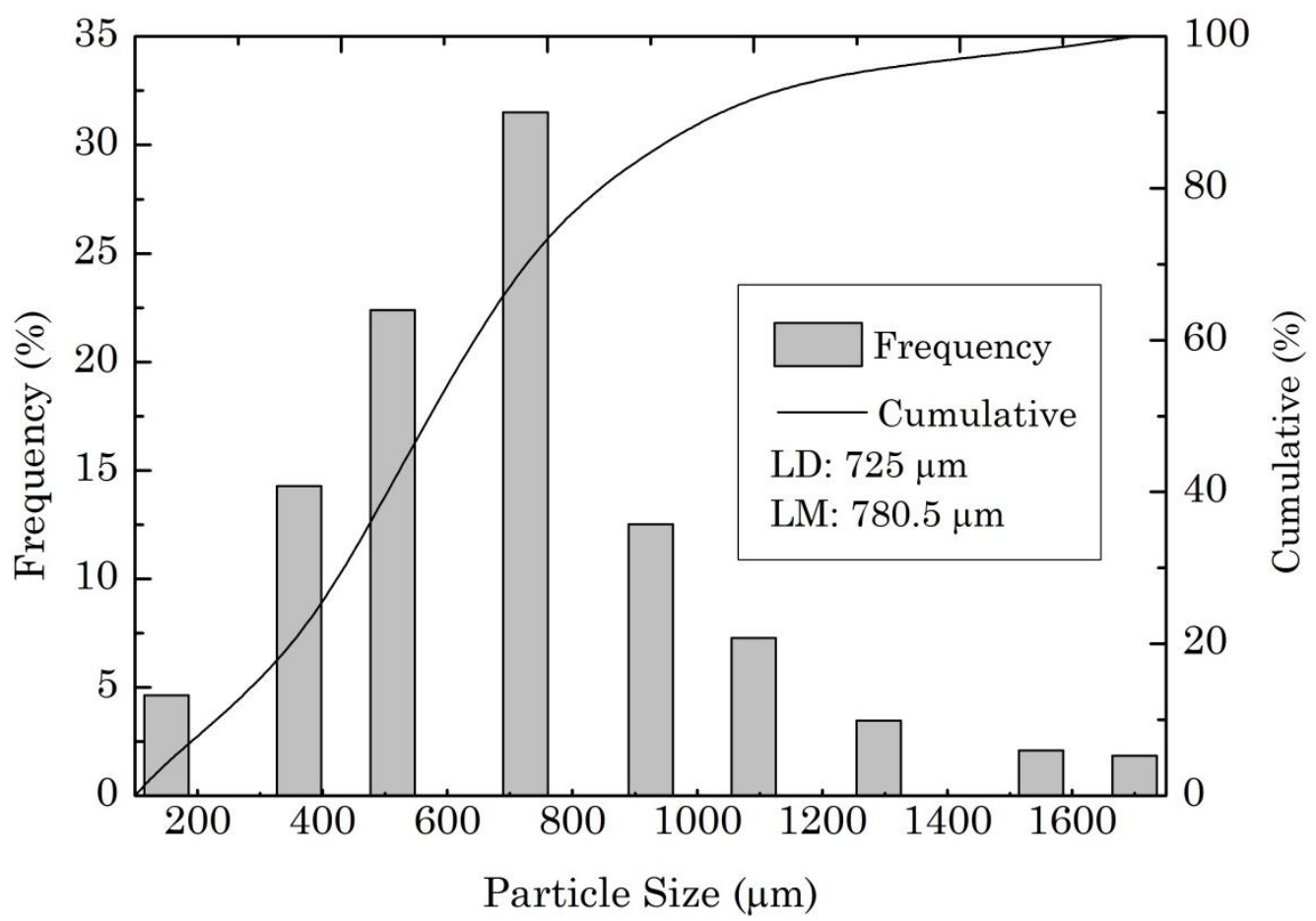

Figure 6: $\mathrm{MgCl}_{2} \cdot 6 \mathrm{H}_{2} \mathrm{O}$ size distribution. $\mathrm{LD}$ (mode size), LM (mean size).

Results showed that LM for bischofite particles was $1560.7 \mu \mathrm{m}$, i.e. $50 \%$ of the particles had sizes larger than this value, while the most repeated particle size (LD) was $1550 \mu \mathrm{m}$. Figure 6 shows size 
distribution for $\mathrm{MgCl}_{2} \cdot 6 \mathrm{H}_{2} \mathrm{O}$, where LD was $725 \mu \mathrm{m}$ and LM $780.51 \mu \mathrm{m}$. Differences in results between bischofite and $\mathrm{MgCl}_{2} \cdot 6 \mathrm{H}_{2} \mathrm{O} 2 \mathrm{O}$ were $825 \mu \mathrm{m}$ in $\mathrm{LM}$ and $780.19 \mu \mathrm{m}$ in $\mathrm{LD}$, with a greater size (double) in the bischofite sample than in the $\mathrm{MgCl}_{2} \cdot 6 \mathrm{H}_{2} \mathrm{O}$ sample.

Particle size is an important property to take into account when carrying out kinetic studies, especially when maintaining isothermal and isobaric conditions. This is because particle size inversely affects reaction kinetics, i.e., reaction kinetics decreases as particle size increases [36]. However, the effect of particle size may be negligible in view of the effect that temperatures and pressures may have. This was the case of the work published by Lin et al., [43], where $\mathrm{CaO}$, with $190 \mu \mathrm{m}$ particle size, showed a faster hydration reaction kinetics compared to $900 \mu \mathrm{m}$ particle size. Nevertheless, this difference turned out to be slight and did not have a significant effect, compared to the effect caused by temperature and pressure. Therefore, size differences between bischofite and $\mathrm{MgCl}_{2} \cdot 6 \mathrm{H}_{2} \mathrm{O}$ are expected to have a minor influence on the studied dehydration reaction kinetics, being more favorable for synthetic $\mathrm{MgCl}_{2} \cdot 6 \mathrm{H}_{2} \mathrm{O}$ material.

\subsection{Thermal decomposition}

When heating bischofite at a rate of $1 \mathrm{~K} / \mathrm{min}$ it was observed that dehydration occurs in four stages, between $80{ }^{\circ} \mathrm{C}$ and $240{ }^{\circ} \mathrm{C}$ (see Figure 7). In the first stage, starting at a temperature of $70{ }^{\circ} \mathrm{C}$ until completion at $95{ }^{\circ} \mathrm{C}$, one water molecule is lost. At the next dehydration stage, starting at a temperature of $95{ }^{\circ} \mathrm{C}$ and ending at $142{ }^{\circ} \mathrm{C}$, three water molecules are lost. The third dehydration stage starts at $142{ }^{\circ} \mathrm{C}$ up to $175{ }^{\circ} \mathrm{C}$, with the loss of the fifth water molecule; finally, the last molecule is lost from $175{ }^{\circ} \mathrm{C}$ to $240{ }^{\circ} \mathrm{C}$ (Table 8). 


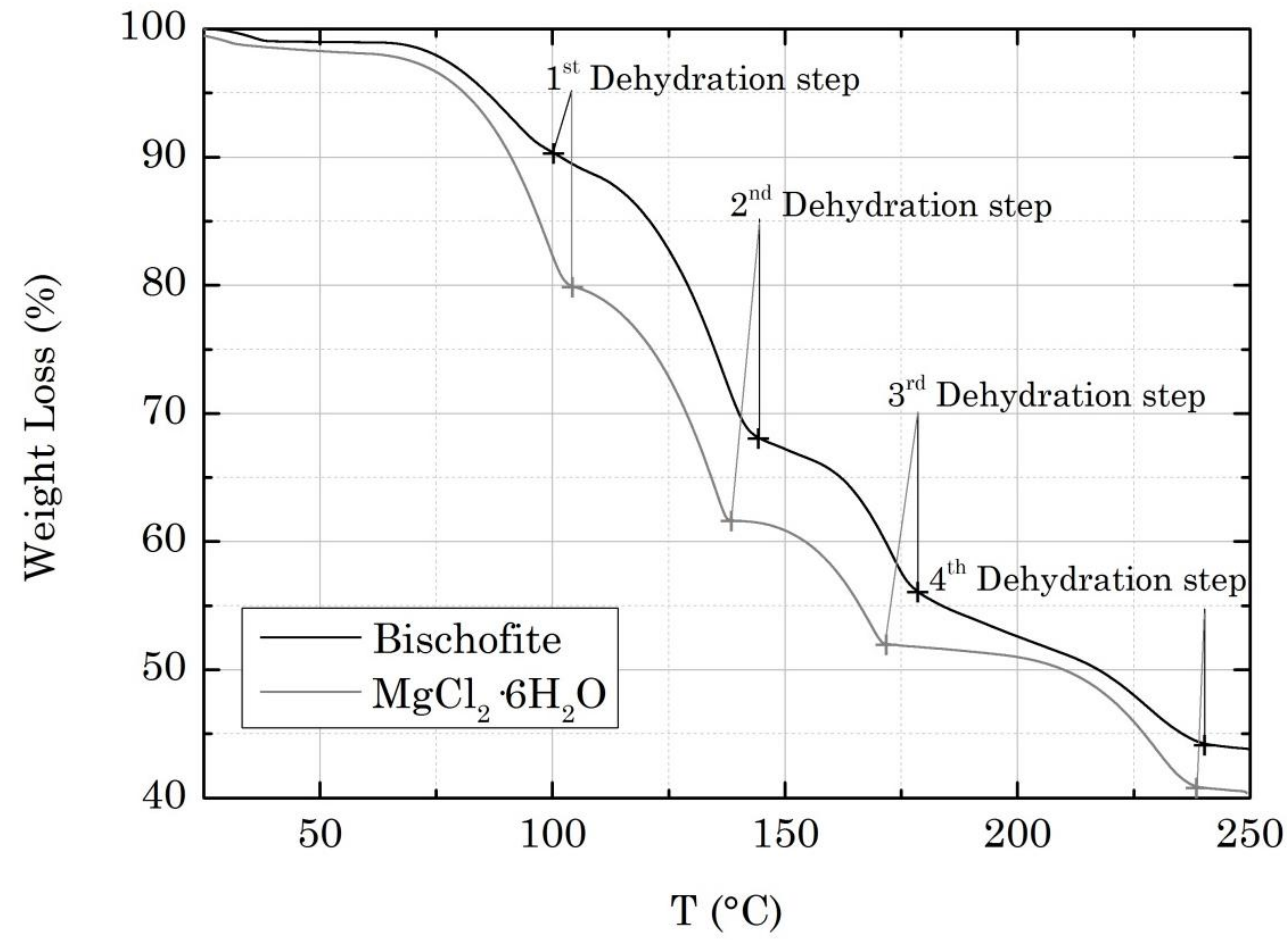

Figure 7: TGA bischofite and $\mathrm{MgCl}_{2} \cdot 6 \mathrm{H}_{2} \mathrm{O}$ measurement. (Heating rate of $1 \mathrm{~K} / \mathrm{min}$ )

Table 8: Bischofite and $\mathrm{MgCl}_{2} \cdot 6 \mathrm{H}_{2} \mathrm{O}$ mass loss in dehydration at a heating rate of $1 \mathrm{~K} / \mathrm{min}$.

\begin{tabular}{lcccc}
\hline \multicolumn{1}{c}{ Materials } & Phase & $\begin{array}{c}\text { Temperature } \\
\left({ }^{\circ} \mathbf{C}\right)\end{array}$ & \% weight loss & $\mathbf{H}_{\mathbf{2}} \mathbf{O}$ mol \\
\hline \multirow{3}{*}{ Bischofite } & 1 & $70-95$ & 8.850 & 1.00 \\
& 2 & $95-142$ & 32.13 & 3.63 \\
& 3 & $142-175$ & 44.17 & 5.00 \\
& 4 & $175-240$ & 55.75 & 6.30 \\
\hline $\mathbf{M g C l}_{2} \cdot \mathbf{6 H}_{\mathbf{2}} \mathbf{O}$ & 1 & $65-110$ & 20.10 & 2.27 \\
& 2 & $110-137$ & 37.94 & 4.29 \\
& 3 & $137-171$ & 47.44 & 5.36 \\
& 4 & $171-236$ & 58.72 & 6.64
\end{tabular}

Results for dehydration of the pure $\mathrm{MgCl}_{2} \cdot 6 \mathrm{H}_{2} \mathrm{O}$ sample, which occurs in four stages as well as for bischofite, are also shown in Figure 7 and Table 8, but losses of the water molecules were found to occur at lower temperatures and times than for bischofite, with a difference of up to $25{ }^{\circ} \mathrm{C}$ and 25 minutes.

Another difference in dehydration of these materials is that the last pure salt dehydration stage is completed with a greater mass loss $(58.72 \%)$ compared to bischofite $(55.75 \%)$ and to the theoretical 53.1 amount. The mass difference is associated with the release of $\mathrm{HCl}$ gas, due to the hydrolysis of $\mathrm{MgCl}_{2} \cdot 2 \mathrm{H}_{2} \mathrm{O}$ since, according to studies [17-21] carried out on $\mathrm{MgCl}_{2} \cdot 6 \mathrm{H}_{2} \mathrm{O}$ thermal decomposition 


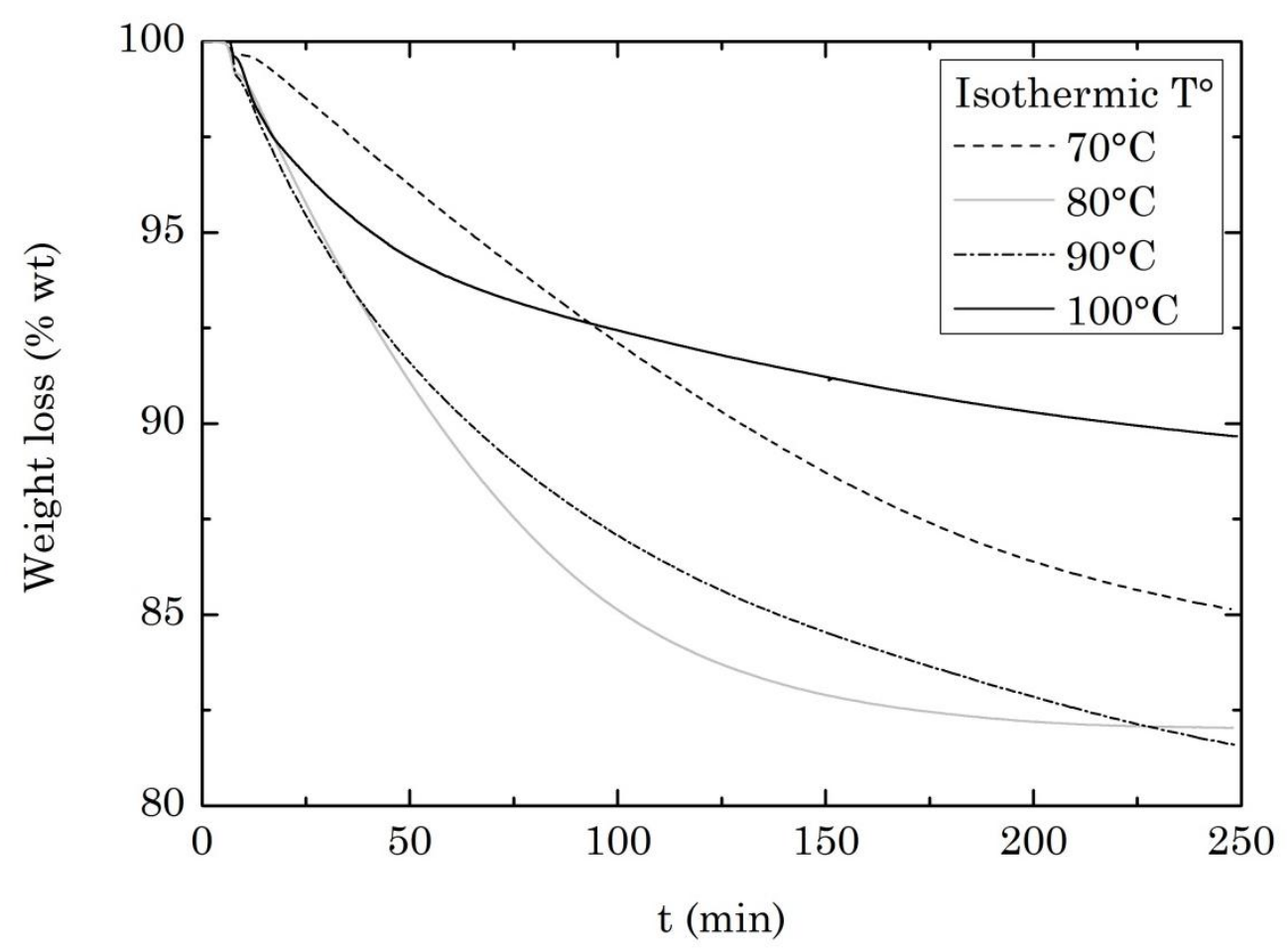

mechanism, $\mathrm{MgCl}_{2} \cdot 2 \mathrm{H}_{2} \mathrm{O}$ dehydration is accompanied by a hydrolysis reaction with the formation of solid $\mathrm{MgOHCl}$ and $\mathrm{HCl}$ gas. The formation of $\mathrm{HCl}$ gas is detrimental to $\mathrm{MgCl}_{2} \cdot 6 \mathrm{H}_{2} \mathrm{O}$ dehydration, because the gas is very corrosive and toxic for use in open energy accumulation reactors. Taking this information into account, the difference in final mass loss, shown between bischofite and $\mathrm{MgCl}_{2} \cdot 6 \mathrm{H}_{2} \mathrm{O}$, would mean an advantage for bischofite with respect to $\mathrm{MgCl}_{2} \cdot 6 \mathrm{H}_{2} \mathrm{O}$, because the release of toxic $\mathrm{HCl}$ gas is lower when completely dehydrating the bischofite sample.

One disadvantage in the thermal behavior of bischofite compared to $\mathrm{MgCl}_{2} \cdot 6 \mathrm{H}_{2} \mathrm{O}$ is the lower $\left(100{ }^{\circ} \mathrm{C}\right.$ instead $\left.115^{\circ} \mathrm{C}\right)$ melting temperature [13], which is undesirable, because melting can lead to destruction of the salt hydrates structure and the formation of an agglomerate, thus reducing the specific area that prevents water absorption during hydration [30]. In addition, phase change hinders the kinetic study of solid-gas states, providing unreliable data [44, 45].

\subsection{Dehydration reaction mechanism and kinetics}

The kinetic study was performed with isothermal regime at four different temperatures, $70{ }^{\circ} \mathrm{C}$, $80{ }^{\circ} \mathrm{C}, 90{ }^{\circ} \mathrm{C}$ and $100{ }^{\circ} \mathrm{C}$. The $100{ }^{\circ} \mathrm{C}$ were set as the maximum limit due to the disadvantage described in the previous section, and the possibility of $\mathrm{HCl}$ gas release during bischofite dehydration. The measurement time for each isotherm was 4 hours, for bischofite and $\mathrm{MgCl}_{2} \cdot 6 \mathrm{H}_{2} \mathrm{O}$, and the mass loss results as a function of time are shown in Figures 8 and 9, respectively. 
Figure 8: Mass loss versus time for bischofite isothermal dehydration at temperatures of $70{ }^{\circ} \mathrm{C}$, $80^{\circ} \mathrm{C}, 90^{\circ} \mathrm{C}$ and $100{ }^{\circ} \mathrm{C}$.

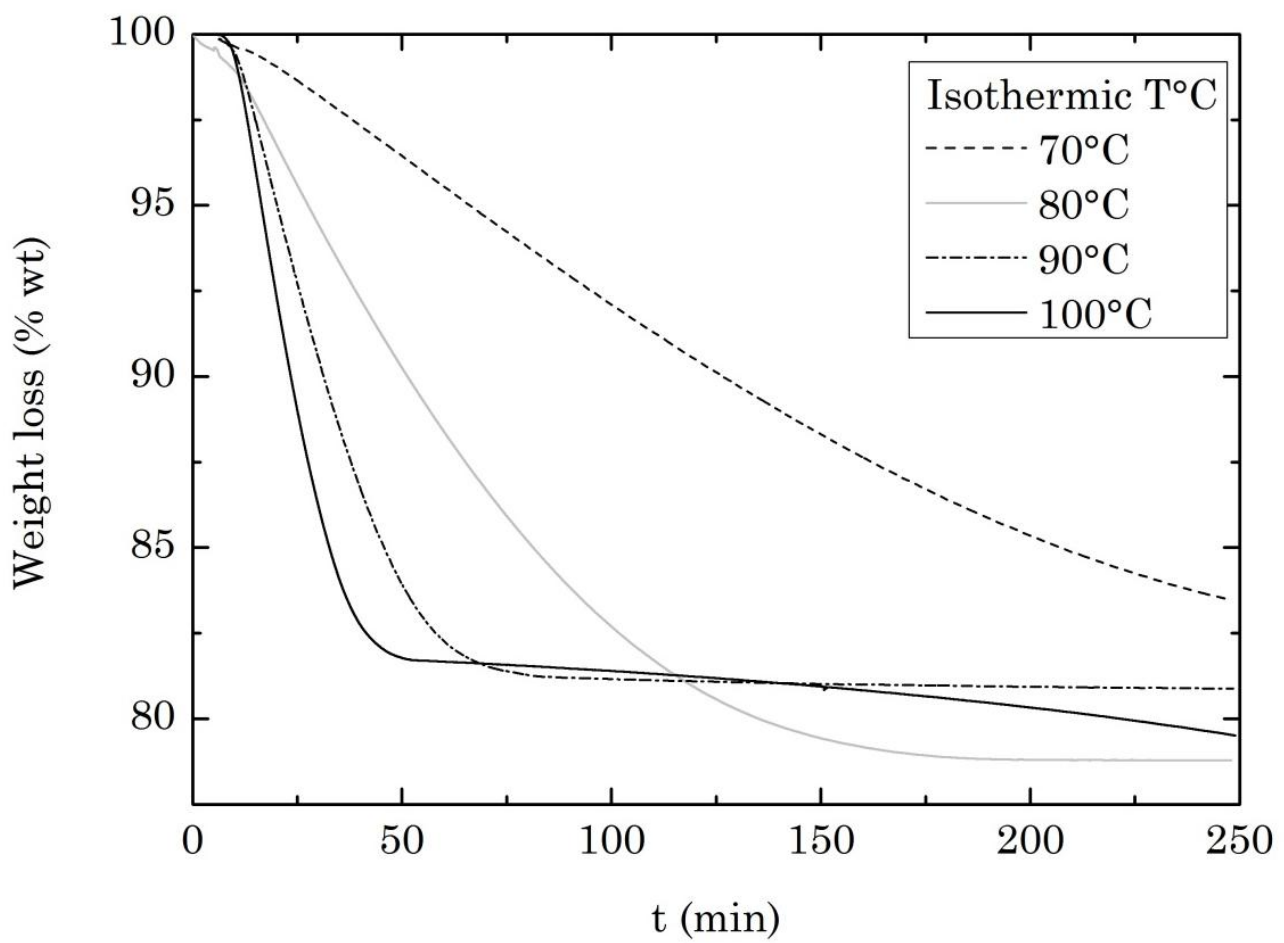

Figure 9: Mass loss versus time for $\mathrm{MgCl}_{2} \cdot 6 \mathrm{H}_{2} \mathrm{O}$ isothermal dehydration at temperatures of $70{ }^{\circ} \mathrm{C}$, $80{ }^{\circ} \mathrm{C}, 90{ }^{\circ} \mathrm{C}$ and $100{ }^{\circ} \mathrm{C}$

Bischofite and $\mathrm{MgCl}_{2} \cdot 6 \mathrm{H}_{2} \mathrm{O}$ isothermal dehydration (see figures 8 and 9) showed that, at $70{ }^{\circ} \mathrm{C}$, to complete the same $17.7 \%$ mass loss (equivalent to 2 water molecules), in both bischofite and $\mathrm{MgCl}_{2} \cdot 6 \mathrm{H}_{2} \mathrm{O}$, reactions are slow and are not complete during the four hours of experimental duration. At higher temperatures $\left(80{ }^{\circ} \mathrm{C}\right.$ and $\left.90{ }^{\circ} \mathrm{C}\right), \mathrm{MgCl}_{2} \cdot 6 \mathrm{H}_{2} \mathrm{O}$ dehydrates 1.9 and 3.8 times faster than bischofite, respectively. At $100{ }^{\circ} \mathrm{C}$, the bischofite dehydration reaction is not complete.

For the bischofite sample (see Figure 8), mass loss occurs more rapidly at a temperature of $80{ }^{\circ} \mathrm{C}$ than at temperatures of $90{ }^{\circ} \mathrm{C}$ and $100{ }^{\circ} \mathrm{C}$. In contrast, for the $\mathrm{MgCl}_{2} \cdot 6 \mathrm{H}_{2} \mathrm{O}$ sample (see Figure 9) it is observed that the mass loss of two water molecules is faster and larger as temperature increases. The reactions at each temperature are listed in Table 9.

Table 9: Bischofite and $\mathrm{MgCl}_{2} \cdot 6 \mathrm{H}_{2} \mathrm{O}$ isothermal dehydration

\begin{tabular}{ccccc}
\hline Materials & $\begin{array}{c}\mathbf{T} \\
\left({ }^{\circ} \mathbf{C}\right)\end{array}$ & \% wt & $\begin{array}{c}\mathbf{H}_{\mathbf{2}} \mathbf{O} \\
(\mathbf{m o l})\end{array}$ & \multicolumn{1}{c}{ Reactions } \\
\hline \multirow{5}{*}{ Bischofite } & 70 & 14.8 & 1.67 & $\mathrm{MgCl}_{2} \cdot 6 \mathrm{H}_{2} \mathrm{O}(\mathrm{s}) \rightarrow \mathrm{MgCl}_{2} \cdot 4.33 \mathrm{H}_{2} \mathrm{O}(\mathrm{s})+1.67 \mathrm{H}_{2} \mathrm{O}(\mathrm{g})$ \\
& 80 & 17.9 & 2.02 & $\mathrm{MgCl}_{2} \cdot 6 \mathrm{H}_{2} \mathrm{O}(\mathrm{s}) \rightarrow \mathrm{MgCl}_{2} \cdot 3.98 \mathrm{H}_{2} \mathrm{O}(\mathrm{s})+2.02 \mathrm{H}_{2} \mathrm{O}(\mathrm{g})$ \\
& 90 & 18.7 & 2.11 & $\mathrm{MgCl}_{2} \cdot 6 \mathrm{H}_{2} \mathrm{O}(\mathrm{s}) \rightarrow \mathrm{MgCl}_{2} \cdot 3.89 \mathrm{H}_{2} \mathrm{O}(\mathrm{s})+2.11 \mathrm{H}_{2} \mathrm{O}(\mathrm{g})$ \\
& 100 & 10.5 & 1.19 & $\mathrm{MgCl}_{2} \cdot 6 \mathrm{H}_{2} \mathrm{O}(\mathrm{s}) \rightarrow \mathrm{MgCl}_{2} \cdot 4.81 \mathrm{H}_{2} \mathrm{O}(\mathrm{s})+1.19 \mathrm{H}_{2} \mathrm{O}(\mathrm{g})$ \\
\hline
\end{tabular}




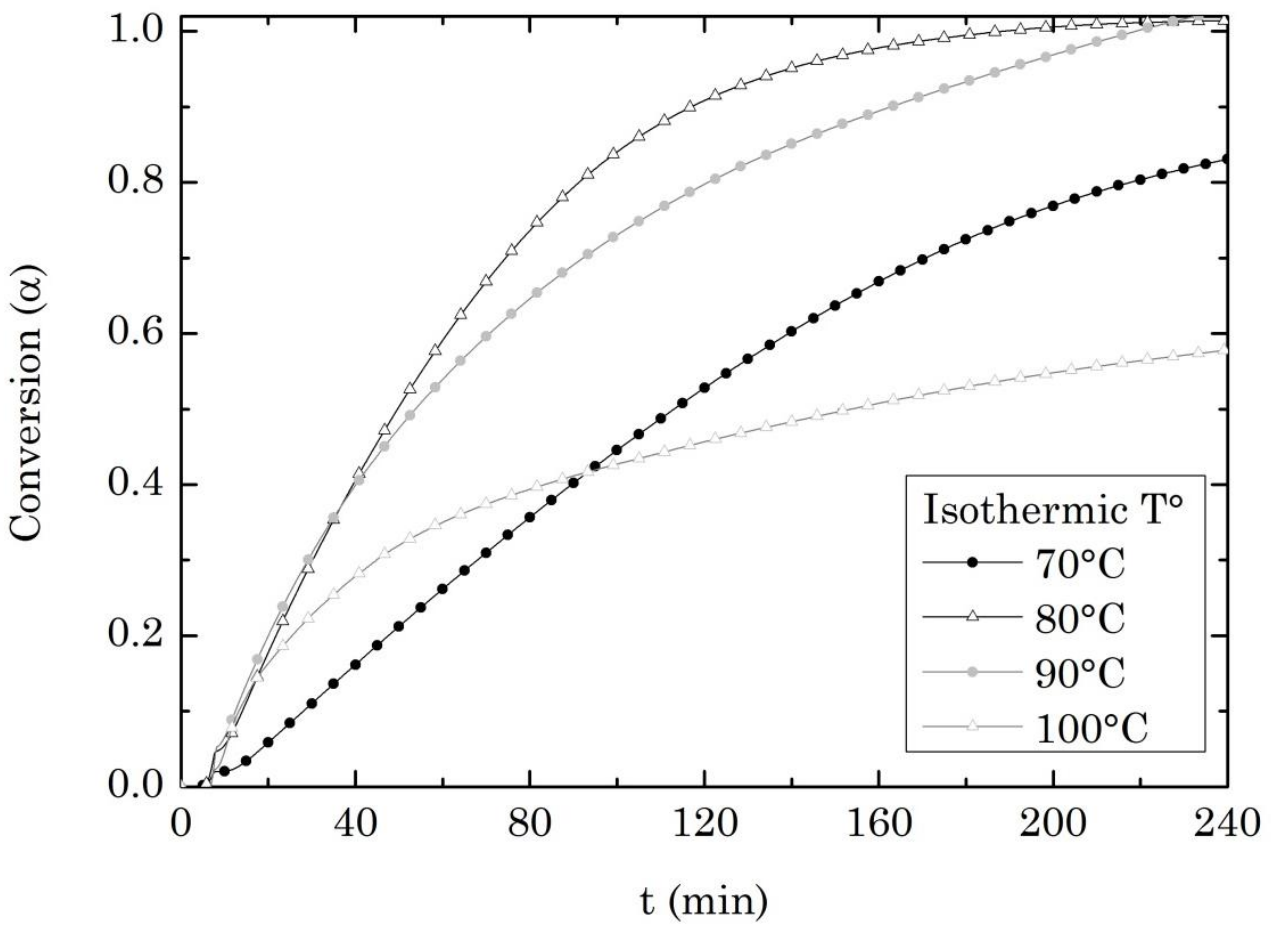

Figure 10: Reacted fraction versus time for bischofite isothermal dehydration at temperatures of 70, 80,90 and $100^{\circ} \mathrm{C}$.

Kinetic curves of the $\mathrm{MgCl}_{2} \cdot 6 \mathrm{H}_{2} \mathrm{O}$ sample (see Figure 11) have two distinguishable shapes, i.e., "decelerating", for temperatures of $70^{\circ} \mathrm{C}$ and $80^{\circ} \mathrm{C}$, and "sigmoid" (S shape) for temperatures of 
$90^{\circ} \mathrm{C}$ and $100^{\circ} \mathrm{C}$ temperatures. Regarding sigmoid curves, these are expected in any decomposition process that occurs by a production control mechanism and growth of nuclei $\left(\mathrm{A}_{2}, \mathrm{~A}_{3}\right.$ and $\left.\mathrm{A}_{4}\right)[44$, 45]. However, kinetic models are more accurately determined by fitting mathematical equations that best represent them. Results are shown in the next section.

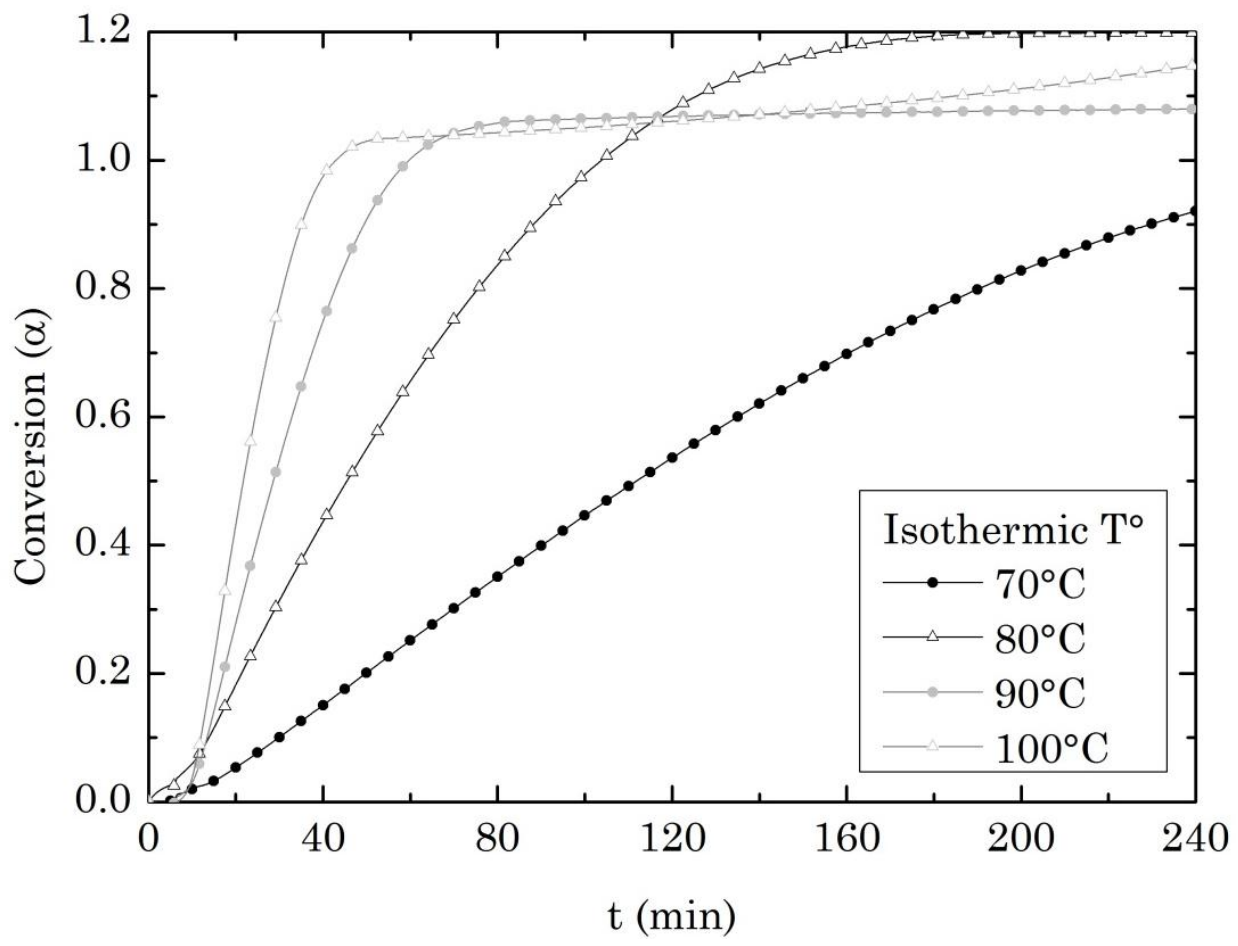

Figure 11: Reacted fraction versus time for the isothermal dehydration of $\mathrm{MgCl}_{2} \cdot 6 \mathrm{H}_{2} \mathrm{O}$ at temperatures of $70^{\circ} \mathrm{C}, 80^{\circ} \mathrm{C}, 90^{\circ} \mathrm{C}$ and $100^{\circ} \mathrm{C}$.

\subsubsection{Bischofite and $\mathrm{MgCl}_{2} \cdot 6 \mathrm{H}_{2} \mathrm{O}$ isothermal dehydration mechanism}

The fitting of thermogravimetric data to more widely used kinetic models [41] was performed by the method of Sharp et al [42], in which plotted data of the reacted fraction $\alpha$ versus the reduced time $\mathrm{t} / \mathrm{t}_{0.5}$ for bischofite and $\mathrm{MgCl}_{2} \cdot 6 \mathrm{H}_{2} \mathrm{O}$ dehydration (Figures 12 and 13) were compared to theoretical fitting data (Figure 3 [46]). 


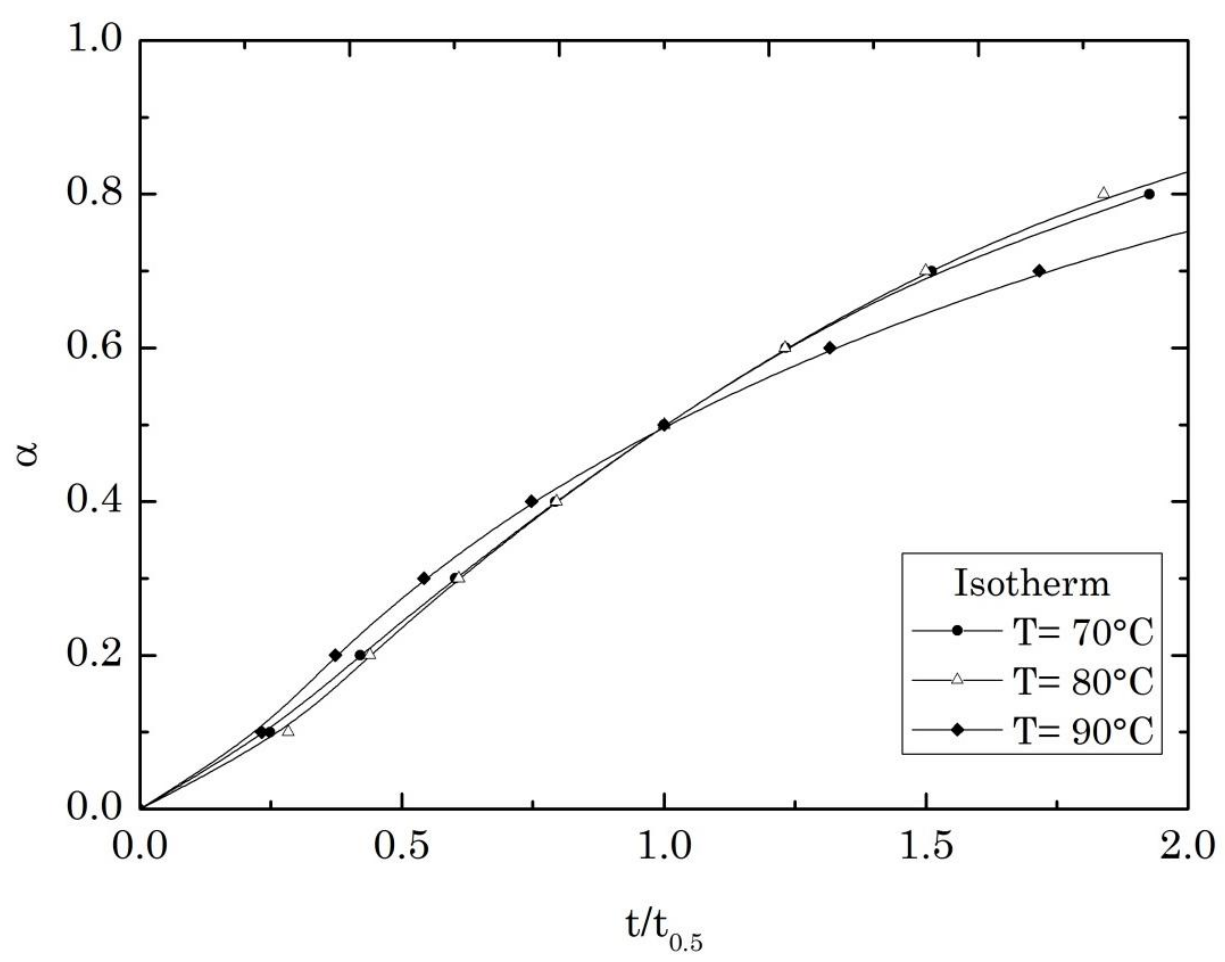

Figure 12: $\alpha$ and $\mathrm{t} / \mathrm{t}_{0.5}$ values for bischofite isothermal dehydration at $70{ }^{\circ} \mathrm{C}, 80{ }^{\circ} \mathrm{C}$ and $90{ }^{\circ} \mathrm{C}$.

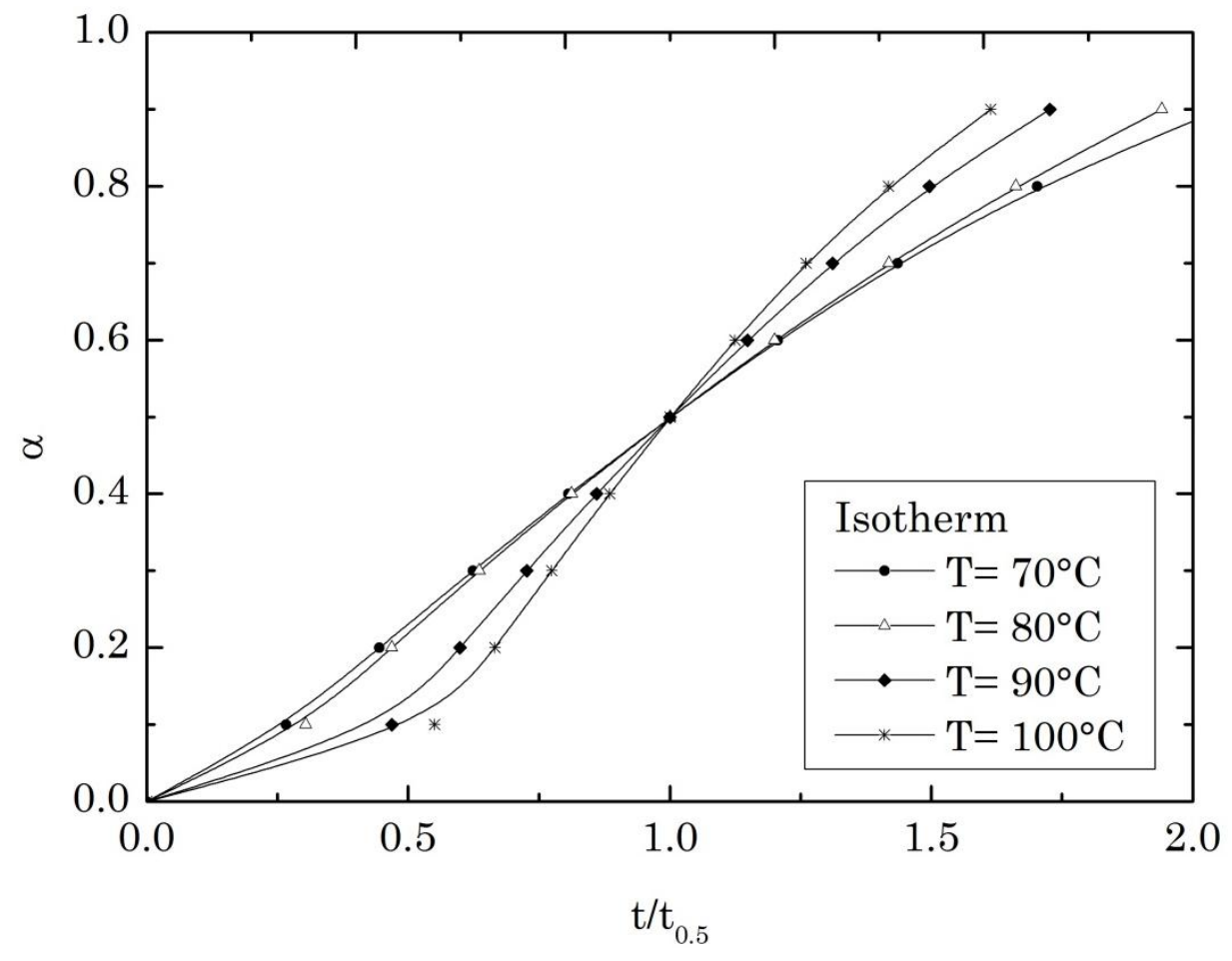

Figure 13: Values of $\alpha$ and $\mathrm{t} / \mathrm{t}_{0.5}$ for $\mathrm{MgCl}_{2} \cdot 6 \mathrm{H}_{2} \mathrm{O}$ isothermal dehydration at $70{ }^{\circ} \mathrm{C}, 80{ }^{\circ} \mathrm{C}, 90{ }^{\circ} \mathrm{C}$ and $100{ }^{\circ} \mathrm{C}$. 
From bischofite fitting results, it was found that $\mathrm{t} / \mathrm{t}_{0.5}$ values fit well to $\mathrm{R}_{2}$ equation over the entire temperature range of $70{ }^{\circ} \mathrm{C}$ and $80{ }^{\circ} \mathrm{C}$. For the temperature of $90{ }^{\circ} \mathrm{C}$, data fit well to $\mathrm{R}_{2}$ equation for $\alpha \leq 0.5$, and to first order $F_{1}$ kinetics for $\alpha \geq 0.5$.

Data fitting performed for $\mathrm{MgCl}_{2} \cdot 6 \mathrm{H}_{2} \mathrm{O}$ shows results different to those of bischofite, where it is observed that, at $70{ }^{\circ} \mathrm{C}$, experimental results fit well to $\mathrm{R}_{2}$ kinetic model, while at $80{ }^{\circ} \mathrm{C}$ they fit well to $\mathrm{R}_{2}$ and $\mathrm{A}_{2}$ and at temperatures of $90{ }^{\circ} \mathrm{C}$ and $100{ }^{\circ} \mathrm{C}$ to $\mathrm{A}_{2}$ and $\mathrm{A}_{3}$ models, respectively.

A more accurate comparison of experimental values with theoretical values was made with the linear relation of $\left(\mathrm{t} / \mathrm{t}_{0.5}\right)_{\text {experimental }}$ with $\left(\mathrm{t} / \mathrm{t}_{0.5}\right)_{\text {theoretical }}$, calculating slope $(b)$, intercept $(a)$ and regression coefficient $(R)$, for bischofite and $\mathrm{MgCl}_{2} \cdot 6 \mathrm{H}_{2} \mathrm{O}$. Results are shown in Table 10 and Table 11, respectively.

Table 10: Comparison of bischofite experimental $\left(\mathrm{t} / \mathrm{t}_{0.5}\right)$ values vs theoretical $\left(\mathrm{t} / \mathrm{t}_{0.5}\right)$ values, according to correlation coefficient, slope and intercept of curves.

\begin{tabular}{|c|c|c|c|c|c|c|c|c|c|}
\hline \multirow{2}{*}{$\begin{array}{l}\text { T } \\
f(\alpha)\end{array}$} & \multicolumn{3}{|c|}{$70^{\circ} \mathrm{C}$} & \multicolumn{3}{|c|}{$80^{\circ} \mathrm{C}$} & \multicolumn{3}{|c|}{$90{ }^{\circ} \mathrm{C}$} \\
\hline & $\mathrm{R}$ & $\mathrm{b}$ & $\mathrm{a}$ & $\mathrm{R}$ & $\mathrm{b}$ & $\mathrm{a}$ & $\mathrm{R}$ & $\mathrm{b}$ & $\mathrm{a}$ \\
\hline$D_{1}(\alpha)$ & 0.9905 & 0.6269 & 0.3272 & 0.9940 & 0.6078 & 0.3472 & 0.9931 & 0.8305 & 0.1931 \\
\hline $\mathbf{D}_{2}(\boldsymbol{\alpha})$ & 0.9761 & 0.5139 & 0.3911 & 0.9816 & 0.4556 & 0.4426 & 0.9969 & 0.6276 & 0.3159 \\
\hline $\mathbf{D}_{3}(\boldsymbol{\alpha})$ & 0.9445 & 0.3923 & 0.4632 & 0.9343 & 0.2944 & 0.5606 & 0.9675 & 0.4095 & 0.471 \\
\hline $\mathbf{D}_{4}(\boldsymbol{\alpha})$ & 0.967 & 0.4708 & 0.4161 & 0.9693 & 0.3965 & 0.4834 & 0.9912 & 0.5481 & 0.3691 \\
\hline $\mathbf{F}_{1}(\alpha)$ & 0.9956 & 0.7629 & 0.1936 & 0.9888 & 0.6562 & 0.2838 & 0.9984 & 0.9013 & 0.1005 \\
\hline $\mathbf{R}_{2}(\boldsymbol{\alpha})$ & 0.9973 & 0.9584 & 0.0623 & 0.9971 & 0.9459 & 0.0783 & 0.9827 & 1.2836 & -0.1646 \\
\hline $\mathbf{R}_{\mathbf{3}}(\boldsymbol{\alpha})$ & 0.9993 & 0.8931 & 0.1062 & 0.9999 & 0.8483 & 0.1458 & 0.9935 & 1.1559 & -0.0784 \\
\hline $\mathbf{A}_{2}(\boldsymbol{\alpha})$ & 0.9878 & 1.4752 & -0.4207 & 0.9910 & 1.4700 & -0.4095 & 0.9693 & 1.9874 & -0.8189 \\
\hline $\mathbf{A}_{3}(\boldsymbol{\alpha})$ & 0.9696 & 2.1068 & -1.0210 & 0.9718 & 2.1863 & -1.0788 & 0.939 & 2.9377 & -1.7055 \\
\hline
\end{tabular}


Table 11: Comparison of $\mathrm{MgCl}_{2} \cdot 6 \mathrm{H}_{2} \mathrm{O}\left(\mathrm{t} / \mathrm{t}_{0.5}\right)$ experimental values vs theoretical $\left(\mathrm{t} / \mathrm{t}_{0.5}\right)$ values, according to correlation coefficient, slope and intercept of curves.

\begin{tabular}{|c|c|c|c|c|c|c|}
\hline \multirow{2}{*}{$\begin{array}{c}\mathbf{T} \\
f(\alpha)\end{array}$} & \multicolumn{3}{|c|}{$70{ }^{\circ} \mathrm{C}$} & \multicolumn{3}{|c|}{$80{ }^{\circ} \mathrm{C}$} \\
\hline & $\mathrm{R}$ & b & $\mathrm{a}$ & $\mathrm{R}$ & $\mathrm{b}$ & $\mathrm{a}$ \\
\hline $\mathbf{D}_{1}(\alpha)$ & 0.9846 & 0.5252 & 0.3949 & 0.9811 & 0.4881 & 0,4309 \\
\hline $\mathbf{D}_{2}(\boldsymbol{\alpha})$ & 0.9549 & 0.3901 & 0.4826 & 0.9455 & 0.3614 & 0.5141 \\
\hline $\mathbf{D}_{3}(\boldsymbol{\alpha})$ & 0.8877 & 0.2491 & 0.5893 & 0.8711 & 0.2298 & 0.6149 \\
\hline $\mathbf{D}_{4}(\boldsymbol{\alpha})$ & 0.9352 & 0.3381 & 0.5198 & 0.9232 & 0.3128 & 0.5493 \\
\hline $\mathbf{F}_{1}(\alpha)$ & 0.9648 & 0.5627 & 0.3456 & 0.9545 & 0.5211 & 0.3874 \\
\hline $\mathbf{R}_{2}(\boldsymbol{\alpha})$ & 0.9989 & 0.822 & 0.1575 & 0.9969 & 0.7645 & 0.2096 \\
\hline $\mathbf{R}_{\mathbf{3}}(\boldsymbol{\alpha})$ & 0.9932 & 0.734 & 0.2197 & 0.9885 & 0.6817 & 0.2685 \\
\hline $\mathbf{A}_{2}(\boldsymbol{\alpha})$ & 0.9987 & 1.2812 & -0.2704 & 0.9970 & 1.1918 & -0.1885 \\
\hline $\mathbf{A}_{3}(\alpha)$ & 0.9909 & 1.9167 & -0.8649 & 0.9922 & 1.7855 & -0.7442 \\
\hline $\mathbf{T}$ & \multicolumn{3}{|c|}{$90{ }^{\circ} \mathrm{C}$} & \multicolumn{3}{|c|}{$100{ }^{\circ} \mathrm{C}$} \\
\hline$f(\alpha)$ & $\mathrm{R}$ & b & $\mathrm{a}$ & $\mathrm{R}$ & b & $\mathrm{a}$ \\
\hline$D_{1}(\alpha)$ & 0.9818 & 0.3713 & 0.5671 & 0.9813 & 0.3123 & 0.6370 \\
\hline $\mathbf{D}_{2}(\boldsymbol{\alpha})$ & 0.9484 & 0.2753 & 0.6299 & 0.9484 & 0.2316 & 0.6897 \\
\hline $\mathbf{D}_{3}(\boldsymbol{\alpha})$ & 0.8771 & 0.1753 & 0.706 & 0.8777 & 0.1476 & 0.7537 \\
\hline $\mathbf{D}_{4}(\boldsymbol{\alpha})$ & 0.9273 & 0.2384 & 0.6565 & 0.9274 & 0.2006 & 0.7121 \\
\hline $\mathbf{F}_{1}(\alpha)$ & 0.9584 & 0.3971 & 0.5332 & 0.9589 & 0.3341 & 0.6083 \\
\hline $\mathbf{R}_{2}(\boldsymbol{\alpha})$ & 0.9978 & 0.5817 & 0.3987 & 0.9977 & 0.4893 & 0.4953 \\
\hline $\mathbf{R}_{\mathbf{3}}(\boldsymbol{\alpha})$ & 0.9903 & 0.5190 & 0.4432 & 0.9904 & 0.4366 & 0.5327 \\
\hline $\mathbf{A}_{2}(\boldsymbol{\alpha})$ & 0.9983 & 0.9070 & 0.0955 & 0.9987 & 0.7631 & 0.2401 \\
\hline $\mathbf{A}_{3}(\boldsymbol{\alpha})$ & 0.9927 & 1.3583 & -0.3268 & 0.9932 & 1.1430 & -0.1154 \\
\hline
\end{tabular}

In order to determine the model that best fits experimental data, the values of slope $b$ and regression coefficient $\mathrm{R}$ are compared. Data with $b$ and $\mathrm{R}$ values closest to one, and values of $a$ closer to zero are those that best fit the kinetic model. According to these fitting results, bischofite dehydration kinetics (see Table 10) at $70{ }^{\circ} \mathrm{C}$ and $80{ }^{\circ} \mathrm{C}$ is best described by the chemical reaction mechanism using $\mathrm{R}_{2}$ kinetic model by means of the cylindrical particle $\mathrm{R}_{2}$ contraction kinetic model. At temperatures of $90{ }^{\circ} \mathrm{C}$, equation models $\mathrm{F}_{1}, \mathrm{R}_{2}$ and $\mathrm{R}_{3}$ also fitted well experimental data.

For $\mathrm{MgCl}_{2} \cdot 6 \mathrm{H}_{2} \mathrm{O}$ (see Table 11), experimental data are fitted to the same, previously predicted kinetic models according to Figure $13, \mathrm{R}_{2}$ for temperatures of $70{ }^{\circ} \mathrm{C}$ and $80{ }^{\circ} \mathrm{C}$, and $\mathrm{A}_{2}$ and $\mathrm{A}_{3}$ at temperatures of $90{ }^{\circ} \mathrm{C}$ and $100{ }^{\circ} \mathrm{C}$, respectively.

In order to better define the fitting kinetic model in bischofite and in $\mathrm{MgCl}_{2} \cdot 6 \mathrm{H}_{2} \mathrm{O}$, linear correlation $\mathrm{R}$ of equations $\mathrm{F}_{1}, \mathrm{R}_{2}$ and $\mathrm{R}_{3}$ was calculated over time for bischofite data, and of 
equations $\mathrm{R}_{2}, \mathrm{R}_{3}, \mathrm{~A}_{2}$ and $\mathrm{A}_{3}$ over time for $\mathrm{MgCl}_{2} \cdot 6 \mathrm{H}_{2} \mathrm{O}$ data. Results are shown in Table 12 and 13 for different amounts of $\alpha$-value points used.

Table 12: Correlation coefficients of experimental data obtained by the least squares method fitted to reaction equations $F_{1}, R_{2}$ and $R_{3}$.

\begin{tabular}{|c|c|c|c|}
\hline \multicolumn{4}{|c|}{ Correlation Coefficients $\mathbf{R}$} \\
\hline$\alpha$ & $\mathbf{F}_{1}(\alpha)$ & $\mathbf{R}_{2}(\boldsymbol{\alpha})$ & $\mathbf{R}_{3}(\boldsymbol{\alpha})$ \\
\hline \multicolumn{4}{|c|}{$\mathbf{T}=\mathbf{7 0}{ }^{\circ} \mathbf{C}$} \\
\hline 240 points & 0.9956 & 0.9953 & 0.9982 \\
\hline 200 points & 0.9932 & 0.9995 & 0.9993 \\
\hline 163 points & 0.9933 & 0.9997 & 0.9989 \\
\hline \multicolumn{4}{|c|}{$\mathbf{T}=\mathbf{8 0}{ }^{\circ} \mathrm{C}$} \\
\hline 180 points & 0.9087 & 0.9860 & 0.9984 \\
\hline 152 points & 0.9827 & 0.9903 & 0.9992 \\
\hline 132 points & 0.9874 & 0.9945 & 0.9996 \\
\hline \multicolumn{4}{|c|}{$\mathbf{T}=90^{\circ} \mathrm{C}$} \\
\hline 210 points & 0.8660 & 0.9897 & 0.9867 \\
\hline 171 points & 0.9959 & 0.9854 & 0.9954 \\
\hline 141 points & 0.9994 & 0.9860 & 0.9942 \\
\hline
\end{tabular}

Table 13: Correlation coefficients of experimental data obtained by the least squares method a fitted to reaction equations $\mathrm{R}_{2}$ y $\mathrm{R}_{3}, \mathrm{~A}_{2}$ and $\mathrm{A}_{3}$.

\begin{tabular}{ccccc}
\hline \multicolumn{5}{c}{ Correlation coefficients $\mathbf{R}$} \\
\hline $\boldsymbol{\alpha}$ & $\mathrm{R}_{2}(\alpha)$ & $\mathrm{R}_{3}(\alpha)$ & $\mathrm{A}_{2}(\alpha)$ & $\mathrm{A}_{3}(\alpha)$ \\
\hline $\mathbf{T}=\mathbf{7 0}{ }^{\circ} \mathbf{C}$ & & & & \\
$\mathbf{2 4 0}$ points & $\mathbf{0 . 9 9 8 4}$ & 0.9919 & 0.9972 & 0.982 \\
$\mathbf{1 9 2}$ points & $\mathbf{0 . 9 9 8 0}$ & 0.9937 & 0.9949 & 0.9753 \\
$\mathbf{1 4 2}$ points & $\mathbf{0 . 9 9 7 7}$ & 0.9952 & 0.9916 & 0.9704 \\
& & & & \\
\hline $\mathbf{T}=\mathbf{8 0}{ }^{\circ} \mathbf{C}$ & & & & \\
$\mathbf{9 6}$ points & $\mathbf{0 . 9 8 7 8}$ & 0.9582 & 0.9579 & 0.9777 \\
$\mathbf{8 2}$ points & $\mathbf{0 . 9 9 6 9}$ & 0.9892 & $\mathbf{0 . 9 9 7 2}$ & 0.9893 \\
$\mathbf{6 2}$ points & $\mathbf{0 . 9 9 8 6}$ & 0.9959 & 0.9957 & 0.9825 \\
\hline $\mathbf{T}=\mathbf{9 0}{ }^{\circ} \mathbf{C}$ & & & & \\
$\mathbf{5 1}$ points & 0.9930 & 0.9679 & 0.9687 & 0.982 \\
$\mathbf{4 2}$ points & 0.9961 & 0.9882 & $\mathbf{0 . 9 9 7 6}$ & 0.9836 \\
$\mathbf{3 1}$ points & 0.996 & 0.9921 & $\mathbf{0 . 9 9 5 2}$ & 0.9768 \\
\hline $\mathbf{T}=\mathbf{1 0 0}{ }^{\circ} \mathbf{C}$ & & & & \\
$\mathbf{3 9}$ points & 0.9954 & 0.9730 & 0.9698 & 0.9846 \\
$\mathbf{2 6}$ points & 0.9961 & 0.9889 & $\mathbf{0 . 9 9 8 3}$ & 0.9856 \\
$\mathbf{2 0}$ points & 0.9954 & 0.9913 & $\mathbf{0 . 9 9 6 8}$ & 0.9812 \\
\hline
\end{tabular}


Finally, based on both fitting methods (the method of Sharp et al, [42], and fitting by the R), it is established that the models that best fit bischofite dehydration experimental data are: $\mathrm{R}_{2}$ (eq. 8 ) at temperatures of 70 and $80{ }^{\circ} \mathrm{C}$ and $\mathrm{F}_{1}$ (eq. 9) at $90{ }^{\circ} \mathrm{C}$.

$$
\begin{aligned}
& \mathrm{R}_{2}:(1-\alpha)^{1 / 2}=k t \\
& \mathrm{~F}_{1}:-\ln (1-\alpha)=k t
\end{aligned}
$$

On the other hand, and according to this analysis, it is possible to determine that the best fits to experimental data of the dehydration of $\mathrm{MgCl}_{2} \cdot 6 \mathrm{H}_{2} \mathrm{O}$ until $\mathrm{MgCl}_{2} \cdot 4 \mathrm{H}_{2} \mathrm{O}$ are for $\mathrm{R}_{2}$ models (eq. 8) at temperatures of $70{ }^{\circ} \mathrm{C}$ and $80{ }^{\circ} \mathrm{C}$ and for the nucleation and growth model of nuclei $\mathrm{A}_{2}$ (eq.10) at temperatures of $90{ }^{\circ} \mathrm{C}$ and $100{ }^{\circ} \mathrm{C}$.

$$
\mathrm{A}_{2}:[-\ln (1-\alpha)]^{1 / 2}=k t
$$

According to previous studies, $\mathrm{R}_{2}$ model found is based on the contraction mechanism of the cylindrical particles area, hence it is assumed that product formation occurs rapidly on the surface of the cylindrical shape particle, and the decomposition rate is controlled by the progress of the chemical reaction in the interface towards the center of the particle [45].

In contrast, $F_{1}$ model is based on the mechanism controlled by first order chemical reaction (limit phase reaction with random nucleation), which is a simpler model, where the reaction rate is proportional to concentration, quantity or remaining fraction of solid reagent used in the dehydration reaction [41].

Kinetics of many solid-state reactions has been described by nucleation models, specifically the Avrami-Erofeyev models $\left(\mathrm{A}_{2}, \mathrm{~A}_{3}\right.$ and $\left.\mathrm{A}_{4}\right)$. These models indicate the formation of a new phase of solid product at the reactive points of the reactant particles (nucleation sites) and growth.

Kinetic studies under non-isothermal conditions, previously performed by Huang et al. [15] for $\mathrm{MgCl}_{2} \cdot 6 \mathrm{H}_{2} \mathrm{O}$ samples, determined that the predominant models for the studied dehydration reaction were found to be $R_{3}$ and $R_{2}$ by chemical reaction, respectively, in each study. These results differ from the isothermal results obtained in this research, because the kinetic mechanisms vary under different experimental conditions [36].

The slower bischofite kinetics compared to $\mathrm{MgCl}_{2} \cdot 6 \mathrm{H}_{2} \mathrm{O}$ dehydration is a disadvantage for applications of the material in processes requiring rapid energy use. However, there are applications, studied by Zondag et al. [20, 30, 33] and Essen et al. [14], using $\mathrm{MgCl}_{2} \cdot 6 \mathrm{H}_{2} \mathrm{O}$ as a seasonal heat storage material. In this type of applications slow kinetics is not an impediment to its 
use, since heat used to charge the material can be stored during the warm seasons (spring and summer), when it is possible to reach temperatures of up to $150^{\circ} \mathrm{C}$ by using solar collectors. This heat can be used in cold seasons (autumn and winter), when ambient temperatures drop significantly. This type of storage, by means of chemical processes, allows heat to be stored for a long period of time, practically without losses, and then used for space and/or sanitary water heating.

Further lab and pilot-scale experimental studies are needed to confirm whether bischofite can be used for seasonal storage. In these studies, measurements of dehydration/hydration cycles should be considered under actual partial vapor pressure and temperature conditions at specified locations.

\subsubsection{Activation energy and frequency factor}

For bischofite and $\mathrm{MgCl}_{2} \cdot 6 \mathrm{H}_{2} \mathrm{O}$ dehydration, the activation energy ( $\mathrm{E}_{\mathrm{a}}$ ) and frequency factor (A) kinetic parameters were calculated according to the rate constants $k$ obtained by plotting equations 8,9 and 10. The results of the calculation of the logarithm of the dehydration reaction rate constant at different temperatures are summarized in Table 14 and plotted in Figure 14, from which the activation energy $E_{a}$ (slope) and frequency factor $A$ (intercept) kinetic parameters were obtained (see Table 15), calculated from the linearized Arrhenius equation (eq. 6).

Table 14: Rate constant values at different temperatures $1 / \mathrm{T}$ to calculate activation energy for bischofite and $\mathrm{MgCl}_{2} \cdot 6 \mathrm{H}_{2} \mathrm{O}$.

\begin{tabular}{ccccc}
\hline & \multicolumn{2}{c}{$\mathbf{M g C l}_{\mathbf{2}} \cdot \mathbf{6 H}_{\mathbf{2}} \mathbf{O}$} & \multicolumn{2}{c}{ Bischofite } \\
\hline $\mathbf{T}\left({ }^{\circ} \mathbf{C}\right)$ & $1 / \mathrm{T} \cdot 10^{3}(1 / \mathrm{K})$ & $\ln k$ & $1 / \mathrm{T} \cdot 10^{3}(1 / \mathrm{K})$ & $\ln k$ \\
\hline $\mathbf{7 0}$ & 2.9144 & -5.7446 & 2.9144 & -5.9522 \\
$\mathbf{8 0}$ & 2.8318 & -4.7217 & 2.8318 & -5.2401 \\
$\mathbf{9 0}$ & 2.7538 & -3.4022 & 2.7538 & -4.0864 \\
$\mathbf{1 0 0}$ & 2.6800 & -2.9450 & & \\
\hline
\end{tabular}




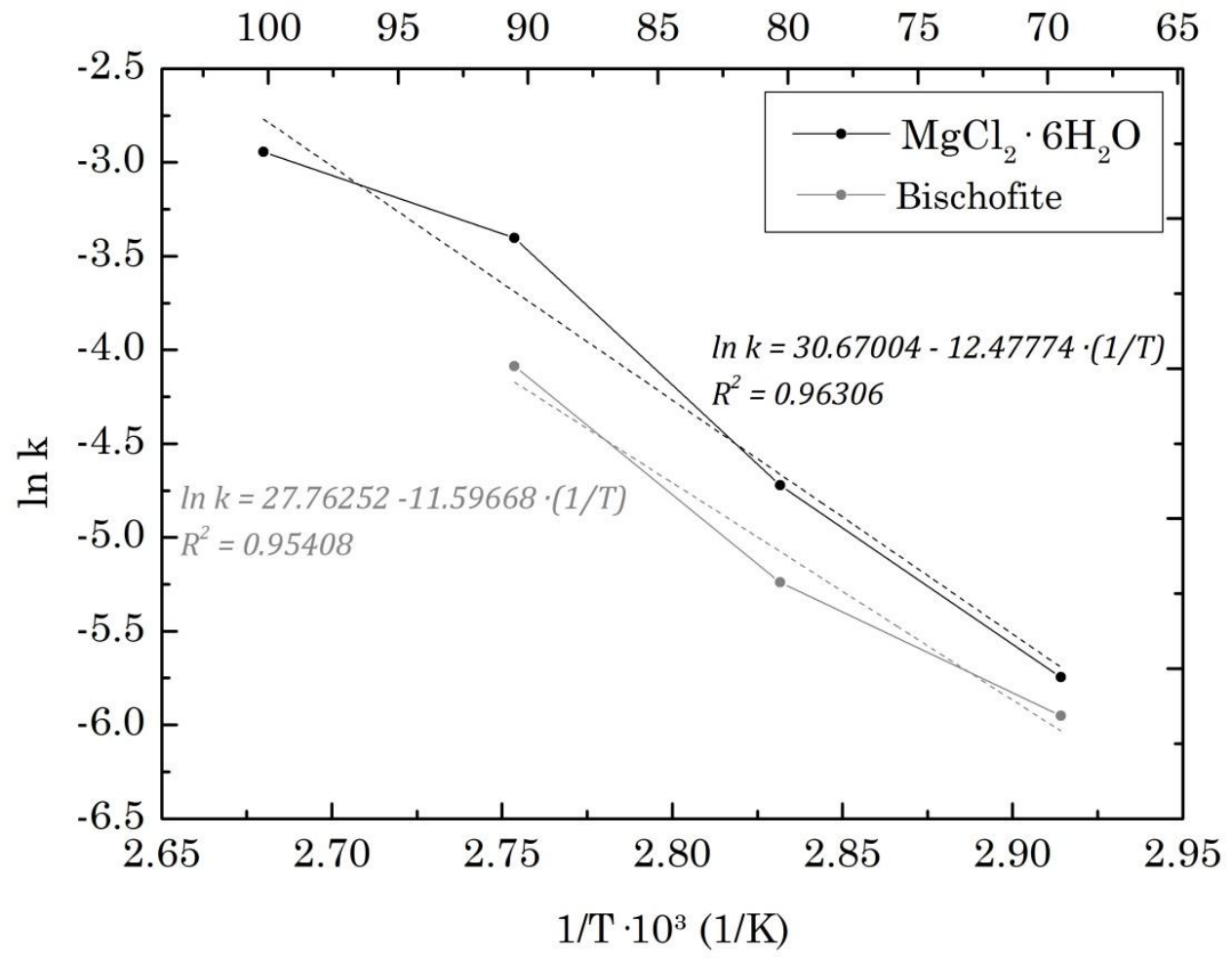

Figure 14: Arrhenius graph using the natural logarithm of rate constants $(\ln k)$ versus the inverse of the temperature in Kelvin $(1 / \mathrm{K})$, according to data in Table 18.

Table 15: Activation energy and frequency factor kinetic parameters for bischofite and $\mathrm{MgCl}_{2}$. $6 \mathrm{H}_{2} \mathrm{O}$.

\begin{tabular}{lccccc}
\hline \multicolumn{1}{c}{ Materials } & $\mathbf{- E}_{\mathbf{a}} / \boldsymbol{R}^{\circ} \mathbf{1 0} \mathbf{0}^{-3}$ & $\mathbf{I n} \mathbf{A}$ & $\mathbf{A}\left(\mathbf{s}^{-1}\right)$ & $\begin{array}{c}\mathbf{E}_{\mathbf{a}} \\
(\mathbf{J} / \mathbf{m o l})\end{array}$ & $\mathbf{R}$ \\
\hline Bischofite & -11.597 & 27.762 & $1.141 \cdot 10^{12}$ & 96414.8 & 0.9541 \\
$\mathbf{M g C l}_{2} \cdot \mathbf{6 H}_{\mathbf{2}} \mathbf{O}$ & -12.478 & 30.670 & $2.088 \cdot 10^{13}$ & 103740.9 & 0.9631 \\
\hline
\end{tabular}

It is important to remember that each kinetic parameter is associated with a fundamental theoretical concept. The activation energy $\left(\mathrm{E}_{\mathrm{a}}\right)$ is associated with the energy barrier to be achieved for a chemical reaction to occur and the frequency factor (A), with the frequency of vibrations of the activated complex and indicates the frequency of collisions between particles. According to this and the results of the kinetic parameters obtained for bischofite, the minimum energy to initiate the dehydration reaction until loss of $2.11 \mathrm{H}_{2} \mathrm{O}$ moles (see Table 9) is $96.415 \mathrm{~kJ} / \mathrm{mol}$, with a collision frequency between particles of $1.141 \cdot 10^{12} \mathrm{~s}^{-1}$ (see Table 15). The minimum energy required by $\mathrm{MgCl}_{2} \cdot 6 \mathrm{H}_{2} \mathrm{O}$ to initiate the dehydration reaction until loss of $2.34 \mathrm{H}_{2} \mathrm{O}$ moles is $103.74 \mathrm{~kJ} / \mathrm{mol}$, with a frequency of collisions between particles of $2.088 \cdot 10^{13} \mathrm{~s}^{-1}$ (see Table 15). 
It should be noted that these kinetic parameters for bischofite and $\mathrm{MgCl}_{2} \cdot 6 \mathrm{H}_{2} \mathrm{O}$ are not in accordance with those found in literature. Huang et al. [15], calculated much lower activation energy and frequency factor values for the first dehydration phase, from $\mathrm{MgCl}_{2} \cdot 6 \mathrm{H}_{2} \mathrm{O}$ to $\mathrm{MgCl}_{2} \cdot 4 \mathrm{H}_{2} \mathrm{O}$, equal to $66.8 \mathrm{~kJ} / \mathrm{mol}$ and 3.6.10 $\mathrm{s}^{-1}$, respectively. These differences can be attributed to the different conditions of the studies performed, as well as to the different calculation methods applied.

In contrast, the kinetic study performed by Kirsh et al., [19], showed activation energy and frequency factor kinetic parameters values equal to $115 \mathrm{~kJ} / \mathrm{mol}$ and $1.9 \cdot 10^{14} \mathrm{~s}^{-1}$, which were indeed closer to those obtained in this study.

\subsection{Energy storage density and storage cost}

The thermal study with TG coupled to DSC provided $\Delta \mathrm{H}_{\mathrm{D}}$ for the dehydration reactions of bischofite and $\mathrm{MgCl}_{2} \cdot 6 \mathrm{H}_{2} \mathrm{O}$ samples at the different working temperatures, which are presented in Table 16. In addition, the amount of energy in Joules (J) that can be stored in $1 \mathrm{~cm}^{3}$ (esd) was calculated for the studied salt hydrate samples and energy storage costs were estimated considering only the cost of the material (see Table 16).

Table 16: Analysis of thermochemical energy storage density and costs.

\begin{tabular}{lcccccc}
\hline Materials & $\begin{array}{c}\text { Temperature } \\
\mathbf{s}\left({ }^{\circ} \mathbf{C}\right)\end{array}$ & $\begin{array}{c}\Delta \mathbf{H}_{\mathbf{D}} \\
(\mathbf{k J} / \mathbf{k g})\end{array}$ & $\begin{array}{c}\boldsymbol{\rho} \text { solid } \\
\left(\mathbf{k g} / \mathbf{m}^{\mathbf{3}}\right)\end{array}$ & $\begin{array}{c}\text { Cost } \\
(\mathbf{U S} \mathbf{k g})\end{array}$ & $\begin{array}{c}\text { esd } \\
\left(\mathbf{J} / \mathbf{c m}^{\mathbf{3}}\right)\end{array}$ & $\begin{array}{c}\text { Energy cost } \\
(\mathbf{U S} \mathbf{S} / \mathbf{M J})\end{array}$ \\
\hline Bischofite & 70 & 440.42 & 1513 & 0.1583 & 666.36 & 0.36 \\
& 80 & 527.66 & $\left(50^{\circ} \mathrm{C}\right)$ & & $\mathbf{7 9 8 . 3 5}$ & $\mathbf{0 . 3 0}$ \\
& 90 & 612.04 & & & 926.02 & 0.26 \\
\hline $\mathbf{M g C l}_{2} \cdot \mathbf{6 ~ \mathbf { H } _ { 2 } \mathbf { O }}$ & 100 & 826.76 & & & 1250.89 & 0.19 \\
& 70 & 445.5 & 1570 & 0.5202 & 699.44 & 1.17 \\
& 80 & 647.66 & $\left(20^{\circ} \mathrm{C}\right)$ & & 1016.82 & 0.80 \\
& 90 & 713.44 & & & 1120.10 & 0.72 \\
\hline
\end{tabular}

According to the results in Table 16, the esd of dehydration of $\mathrm{MgCl}_{2} \cdot 6 \mathrm{H}_{2} \mathrm{O}$ and bischofite are in accordance with table 2 values to the releasing of 2 water molecules at $100^{\circ} \mathrm{C}$, where $e s d$ is similar or even greater than found in literature. But the main importance of this table is that bischofite has a 
lower esd than $\mathrm{MgCl}_{2} \cdot 6 \mathrm{H}_{2} \mathrm{O}$, with a difference ranging from $4.73 \%$ to $21.49 \%$ between the different temperatures. However, at $100{ }^{\circ} \mathrm{C}$, the calculated cost to store 1 Mega Joule of energy, as thermochemical energy, for bischofite was found to be three times smaller than storage cost using $\mathrm{MgCl}_{2} \cdot 6 \mathrm{H}_{2} \mathrm{O}$.

In addition, according to the study by Ushak et al. [13], when using bischofite to store energy as latent heat, the energy density obtained was $170 \mathrm{~J} / \mathrm{cm}^{3}$, energy seven times lower than the one obtained with bischofite when used as thermochemical material at $100{ }^{\circ} \mathrm{C}\left(1251 \mathrm{~J} / \mathrm{cm}^{3}\right)$. Cost to store energy as latent heat is $1.28 \mathrm{US} \$ \mathrm{MJ}$ [47], almost seven times greater than the one obtained to store thermochemical heat in bischofite (0.915 US\$/MJ).

\section{CONCLUSIONS}

The viability of storing thermochemical energy in bischofite, a waste material containing $97.39 \%$ of $\mathrm{MgCl}_{2} \cdot 6 \mathrm{H}_{2} \mathrm{O}$ in its composition, has been experimentally demonstrated in this study, by means of the dehydration reaction of this material at different temperatures. Dehydration, at a constant rate of $1 \mathrm{~K} / \mathrm{min}$, showed that the reaction occurs in four stages of water molecules loss, at times and temperatures slightly higher, up to about $25^{\circ} \mathrm{C}$ and 25 minutes, than in $\mathrm{MgCl}_{2} \cdot 6 \mathrm{H}_{2} \mathrm{O}$ samples. The fastest dehydration kinetics for bischofite was obtained at $80{ }^{\circ} \mathrm{C}$ (isotherm) compared to temperatures of $90{ }^{\circ} \mathrm{C}$ and $100{ }^{\circ} \mathrm{C}$. Bischofite kinetics, compared to that of $\mathrm{MgCl}_{2} \cdot 6 \mathrm{H}_{2} \mathrm{O}$ ore, was generally up to four times slower, which could be affected by the impurity factors contained in bischofite, as well as, to a lesser extent, by particle size, which turned out to be twice that of the $\mathrm{MgCl}_{2} \cdot 6 \mathrm{H}_{2} \mathrm{O}$ sample.

The study of the bischofite dehydration mechanism, by means of the fitting of experimental kinetic data, allowed to determine the $\mathrm{R}_{2}$ model (cylindrical particle contraction) at $70{ }^{\circ} \mathrm{C}$ and $80{ }^{\circ} \mathrm{C}$ and $\mathrm{F}_{1}$ (first order reaction) at $90{ }^{\circ} \mathrm{C}$, which are based on the control mechanism by chemical reactions in limit phase for bischofite. Results for $\mathrm{MgCl}_{2} \cdot 6 \mathrm{H}_{2} \mathrm{O}$ at $90{ }^{\circ} \mathrm{C}$ and $100{ }^{\circ} \mathrm{C}$ were different, and resulted in nucleation and particle growth: $\mathrm{A}_{2}$.

Finally, the study of bischofite energy storage density (esd) showed a slightly lower value than that of $\mathrm{MgCl}_{2} \cdot 6 \mathrm{H}_{2} \mathrm{O}$, but storage costs for $1 \mathrm{MJ}$ of bischofite thermochemical energy at $100{ }^{\circ} \mathrm{C}$ was found to be three times lower than that of $\mathrm{MgCl}_{2} \cdot 6 \mathrm{H}_{2} \mathrm{O}$ and seven times smaller than the type of energy stored as latent heat. Thus, this work demonstrated the potential for reuse of bischofite in 
seasonal thermochemical storage, as a way to use cleaner energy and to help decrease the accumulation of nonmetallic mining waste.

\section{ACKNOWLEDGEMENTS}

Verónica Mamani thanks CONICYT for her doctorate scholarship CONICYT No 21150145. Svetlana Ushak thanks financial support CONICYT/FONDAP $\mathrm{N}^{\circ} 15110019$ SERC-Chile and FONDECYT N 1170675.

\section{REFERENCES}

1. Kalaiselvan and Parameshwaran, Energy and energy management, Thermal Energy Storage Technologies for Sustainability, Chapter 1(2014) 1-19.

2. Atul Sharma, V.V. Tyagi, C.R. Chen, D. Buddhi. Review on thermal energy storage with phase change materials and applications. Renewable and Sustainable Energy Reviews 13 (2009) 318-345.

3. Pielichowska K., Pielichowski K. Phase change materials for thermal energy storage. Progress in materials science, 65 (2014) 67-123.

4. Ali Haji Abedin, Marc A. Rosen. Closed and open thermochemical energy storage: Energyand exergy-based comparisons. Energy, Volume 41, Issue 1 (2012) Pages 83-92.

5. Juan Wu and Xin feng Long. Research progress of solar thermochemical energy storage. Int. J. Energy Res.; 39 (2015) 869-888.

6. Amar Deep Pathak, Silvia Nedea, Herbert Zondag, Camilo Rindt and David Smeulders. A DFT-based comparative equilibrium study of thermal dehydration and hydrolysis of $\mathrm{CaCl} 2$ hydrates and $\mathrm{MgCl} 2$ hydrates for seasonal heat storage. Phys. Chem. Chem. Phys., 2016,18, 10059-10069

7. Ferchaud, C., Zondag, H. A., Boer, de, R., Rindt, C. C. M. (2012). Characterization of the sorption process in thermochemical materials for seasonal solar heat storage application. In Proceedings of the 12th International conference on Energy Storage (Innostock 2012), 1618 May 2012, Lleida, Spain. (pp. 1-10). Technische Universiteit Eindhoven.

8. Xinyue Peng, Thatcher W. Root, Christos T. Maravelias. Storing solar energy with chemistry: the role of thermochemical storage in concentrating solar power. Green Chem., 2017, Advance Article, doi 10.1039/C7GC00023E 
9. P. Pardo, A. Deydiera, Z. Anxionnaz-Minvielle, S. Rougé, M.Cabassud, P.Cognet. A review on high temperature thermochemical heat energy storage. Renewable and Sustainable Energy Reviews 32 (2014) 591-610.

10. T. Yan, R. Z. Wang, T. X. Li, L.W. Wang, Ishugah T. Fred, A review of promising candidate reactions for chemical heat storage. Renewable and Sustainable Energy Reviews, 43 (2015) 13-31.

11. Jaume Cot-Gores, Albert Castell, Luisa F. Cabeza. Thermochemical energy storage and conversion: A-state-of-the-art review of the experimental research under practical conditions. Renewable and Sustainable Energy Reviews 16 (2012) 5207-5224.

12. S. Ushak, A. Gutierrez, Y. Galazutdinova, C. Barreneche, L. F. Cabeza, M. Grágeda. Influence of alkaline chlorines on thermal energy storage properties of bischofite. International Journal of Energy Research, (2016) p.1556-1563.

13. Svetlana Ushak, Andrea Gutierrez, Hector Galleguillos, Angel G. Fernandez, Luisa F. Cabeza, Mario Grágeda. Thermophysical characterization of a by-product from the nonmetallic industry as inorganic PCM Solar Energy Materials \& Solar Cells 132 (2015); 385 391.

14. Van Essen, V. M., Cot Gores, J., Bleijendaal, L. P. J., Zondag, H. A., Schuitema, R., van Helden, W. G. J. ECN, (2009).

15. Qiong-Zhu Huang, Gui-Min Lu, Jin Wang, And Jian-Guo Yu. Mechanism and kinetics of thermal decomposition of $\mathrm{MgCl}_{2} \cdot 6 \mathrm{H}_{2} \mathrm{O}$. The Minerals, Metals \& Materials Society and ASM International 2010.

16. Qiongzhu Huang, Guimin Lu, Jin Wang, Jianguo Yu. Thermal decomposition mechanisms of $\mathrm{MgCl} 2 \cdot 6 \mathrm{H} 2 \mathrm{O}$ and $\mathrm{MgCl} 2 \cdot \mathrm{H} 2 \mathrm{O}$. Journal of Analytical and Applied Pyrolysis 91, 159164 (2011).

17. S. Kashani-Nejad, R. Harris. Oxides formed during the dehydration of magnesium chloride hexahydrate, in: Magnesium Technology in the Global Age, 2006, pp. 81-92 (Canada) (2006).

18. Kunihisa Sugimoto, Robert E. Dinnebier, Jonathan C. Hanson. Structures of three dehydration products of bischofite from in situ synchrotron powder diffraction data $(\mathrm{MgCl} 2 * n \mathrm{n} 2 \mathrm{O} ; \mathrm{n}=1,2,4)$. Acta Crystallographica Section B 63; 235-242. (2007).

19. Y. Kirsh, S. Yariv, S. Shoval. Kinetic analysis of thermal dehydration and hydrolysis of $\mathrm{MgCl} 2 * 6 \mathrm{H} 2 \mathrm{O}$ by DTA and TG. Journal of Thermal Analysis, Vol 32, 1 (1987) 393-408. 
20. Zondag HA, van Essen VM, Bleijendaa L PJ, Kikkert BWJ, Bakker M. Application of $\mathrm{MgCl} 2 * 6 \mathrm{H} 2 \mathrm{O}$ for thermochemical seasonal solar heat storage; (2010). Available from: 〈ftp:// ftp. ecn. nl/ pub/ www/ library/ report/ 2010/ m 10094. pdf $\rangle$.

21. Holger Urs Rammelberg, Thomas Schmidt, Wolfgang Ruck, Hydration and dehydration of salt hydrates and hydroxides for thermal energy storage - kinetics and energy release, Energy Procedia, 30 (2012) 362 - 369.

22. S. Cantor, DSC study of melting and solidification of salt hydrates, Thermochim. Acta 33(1979) 69-82.

23. H.O. Paksoy, Thermal Energy Storage for Sustainable Energy Consumption: Fundamentals, Case Studies and Design, Springer, (2007) pp. 257-263.

24. M.F. Demirbas, Thermal energy storage and phase change materials: an overview, Energy Sources 1 (2006) 85-95.

25. K. Nagano, K. Ogawa, T. Mochida, K. Hayashi, H. Ogoshi, Thermal characteristics of magnesium nitrate hexahydrate and magnesium chloride hexahydrate mixture as a phase change material for effective utilization of urban waste heat, Appl. Therm. Eng. 24 (2004) 221-232.

26. M.M. Farid, A.M. Khudhair, S.A.K. Razack, S. Al-Hallaj, A review on phase change energy storage: materials and applications, Energy Convers. Manage. 45 (2004) 15971615.

27. P. Patnaik, Handbook of Inorganic Chemicals, McGraw-Hill Professional, New York, (2002) p. 521.

28. A. Abhat, Low temperature latent heat thermal energy storage: heat storage materials, Sol. Energy 30 (1983), 313-332.

29. C.L. Yaws, Handbook of Thermodynamic Properties for Hydrocarbons and Chemicals, Knovel, New York, (2009).

30. Zondag H.A., Kikkert B. W. J., Smeding S., Bakker M. Thermochemical seasonal solar heat storage with $\mathrm{MgCl} 2.6 \mathrm{H} 2 \mathrm{O}$ : first up scaling of the reactor. In: Proceedings of the international conference for sustainable energy storage; (2011).

31. Opel O, Rammelberg HU, Gérard M, Ruck W. Thermochemical storage materials research -TGA/DSC- hydration studies. In: Proceedings of the international conference for sustainable energy storage; (2011).

32. Kokouvi Edem N'Tsoukpoe, Thomas Schmidt, Holger Urs Rammelberg, Beatriz Amanda Watts, Wolfgang K.L. Ruck. A systematic multi-step creening of numerous salt hydrates for low temperature thermochemical energy storage. Applied Energy 124 (2014) 1-16. 
33. Zondag H, Kikkert B, Smeding S, Rd Boer, Bakker M. Prototype thermochemical heat storage with open reactor system. Appl Energy; 109 (2013) 360-5.

34. S. Kashani-Nejad, K.W. Ng, R. Harris, Preparation of $\mathrm{MgOHCl}$ by controlled dehydration of $\mathrm{MgCl} 2 \cdot 6 \mathrm{H} 2 \mathrm{O}$, Metall. Mater. Trans. B 35, (2004).

35. S. Kashani-Nejad, K.W. Ng, R. Harris, MgOHCl thermal decomposition kinetics, Metall. Mater. Trans. B 36 (2005) 153-157.

36. Aran Sole, Xavier Fontanet, Camila Barreneche, Ana I. Fernández, Ingrid Martorell, Luisa F. Cabeza. Requirements to consider when choosing a thermochemical material for solar energy storage. Solar Energy 97 (2013) 398-404.

37. Ushak S, Gutierrez A. Flores E, Galleguillos H, Grageda M, Development of Thermal Energy Storage Materials from Waste-Process Salts. Energy Procedia 2014; 57: 627-632 (2013 ISES Solar World Congress).

38. Gutierrez A, Galazutdinova Y, Vargas P, Grágeda M, Ushak S, Heat-treated material for sensible heat storage from waste of non-metallic industry. Materials Science and Technology Conference and Exhibition 2014 (MS\&T): 1675-1680.

39. Characterization of wastes based on inorganic double salt hydrates as potential thermal energy storage materials. Andrea Gutierrez, Svetlana Ushak, Veronica Mamani, Pedro Vargas, Camila Barreneche, Luisa F. Cabeza, Mario Grágeda. Solar Energy Materials and Solar Cells (2017) doi: 10.1016/j.solmat.2017.05.036

40. A. Gutierrez, A. Gil, J. Rodríguez-Aseguinolaza, C. Barreneche, N. Calvet, X. Py, A. I. Fernández, M. Grágeda, S. Ushak, L.F. Cabeza, Review on industrial waste and by-product materials revalorization as thermal energy storage (TES) materials, Renew. Sust. Energ. Rev., 59 (2013) 763 - 783.

41. I. Halikia, P. Neou- Syngouna, D. Kolitsa. Isothermal Kinetic analysis of the thermal decomposition of magnesium hydroxide using thermogravimetric data. Thermochimical. Acta 320 (1998) 75-88.

42. J.H. Sharp, G.W. Brindley, B.N. Narahari, Achar, Journal of the American Ceramic Society 49(7) 379 (1966).

43. Lin, S., Harada, M., Suzuki, Y., Hatano, H. CaO hydration rate at high temperature (1023 K). Energ. Fuel 20 (2006), 903-908.

44. Vyazovkin, S., Burnham, A.K., Criado, J.M., Pérez-Maqueda, L.A., Popescu, C., Sbirrazzuoli, N. ICTACinetics committee recommendations for performing kinetic computations on thermal analysis data. Thermochim. Acta 520 (2011) 1-19. 
45. Ammar Khawam, and Douglas R. Flanagan. Solid-State Kinetic Models: Basics and Mathematical Fundamentals. J. Phys. Chem. B, 110 (35) (2006) 17315-17328.

46. Iliana Halikia, Antonia Economacou. Application of Various Methods of Nonisothermal Kinetic Analysis to Magnesium Hydroxide Decomposition. International Journal of Chemid Kinetics, Vol. 25 (1993) 609-631.

47. Svetlana Ushak, Andrea Gutierrez, Camila Barreneche, A. Inés Fernandez, Mario Grágeda, Luisa F. Cabeza. Reduction of the subcooling of bischofite with the use of nucleatings agents. Solar Energy Materials \& Solar Cells 157 (2016) 1011-1018. 